OPEN ACCESS

Edited by:

Jian-Guo Huang,

Chinese Academy of Sciences, China

Reviewed by:

Hanxue Liang,

Chinese Academy of Sciences, China

Marcin Klisz,

Forest Research Institute (IBL), Poland

*Correspondence:

Benjamin Marquis

benjamin.marquis@uqat.ca

Specialty section:

This article was submitted to Functional Plant Ecology,

a section of the journal

Frontiers in Plant Science

Received: 19 March 2020 Accepted: 23 June 2020

Published: 22 July 2020

Citation:

Marquis $B$, Bergeron $Y$, Simard $M$ and Tremblay $F$ (2020) Probability of Spring Frosts, Not Growing Degree-Days, Drives Onset of Spruce Bud Burst in Plantations at the Boreal-Temperate Forest Ecotone.

Front. Plant Sci. 11:1031. doi: $10.3389 /$ fpls.2020.01031

\section{Probability of Spring Frosts, Not Growing Degree-Days, Drives Onset of Spruce Bud Burst in Plantations at the Boreal-Temperate Forest Ecotone}

\author{
Benjamin Marquis $^{1 *}$, Yves Bergeron ${ }^{1,2}$, Martin Simard $^{3}$ and Francine Tremblay ${ }^{1}$ \\ 1 Institut de Recherche sur les Forêts, Université du Québec en Abitibi Témiscamingue, Rouyn-Noranda, QC, Canada, \\ 2 Département de Sciences Biologiques, Université du Québec à Montréal, Montréal, QC, Canada, ${ }^{3}$ Department of \\ Geography, Centre for Forest Research, and Centre for Northern Studies, Laval University, Québec, QC, Canada
}

Climate warming-driven early leaf-out is expected to increase forest productivity but concurrently increases leaf exposure to spring frosts, which could reduce forests' net productivity. We hypothesized that due to their damaging effect on buds, spring frosts exert a stronger control on bud phenology than do growing degree-days. We monitored bud flush phenology of three white spruce seed sources (one local seed source from the boreal mixedwood forest and two seed sources from the temperate forest), one black spruce seed source originating from the boreal mixedwood forest and four nonlocal Norway spruce seed sources in 2016 and 2017 in two plantations located on both sides of the temperate-boreal mixedwood forest ecotone in eastern Canada (Quebec). We aimed to determine inter- and intraspecies variations in bud break timing and sensitivity to air temperature and photoperiod. We expected that bud break timing for boreal species and seed sources would be better synchronized with the decrease in frost probability than for nonlocal species and seed sources. We used mixed binomial regressions and AICC model selection to determine the best environmental variables predicting each transition from one stage of bud phenology to the next. At both plantation sites, white spruce bud flush began and ended earlier compared to black and Norway spruce. Buds of all spruce species were sensitive to frost probability for early phenological stages, whereas growing degree-days controlled the remaining stages. Photoperiod sensitivity was higher for white spruce compared to black and Norway spruce and reached its maximum in the temperate forest. At intraspecies level, the two southern white spruce seed sources opened their buds earlier than the local source and were more sensitive to photoperiod, which increased their exposure to spring frosts. Onset of spruce bud flush is driven by spring frosts and photoperiod, but once started, bud phenology responds to temperature. The high photoperiod sensitivity in white spruces could counterbalance climate warming and limit future premature leaf-out, whereas the low photoperiod sensitivity in black spruce should not restrain leaf-out advancement with climate warming. Our results call for 
adapting the temperature-driven hypotheses of ecophysiological models predicting leafout to include spring frost probability.

Keywords: bud phenology, growing degree-days, leaf-out, photoperiod, Picea, spring frost, temperature, thermal acclimation

\section{INTRODUCTION}

The observed $1^{\circ} \mathrm{C}$ increase in mean global air temperature above preindustrial levels (1850-2017; Allen et al., 2018) is desynchronising tree phenology from tracking the seasonal variation in air temperature by triggering earlier spring leaf-out (Parmesan and Yohe, 2003; Piao et al., 2007; Polgar et al., 2013) and later entrance into dormancy (Jeong et al., 2011; Liu et al., 2016; Fu et al., 2017). The earlier onset and the later ending of the growing season expose frost-sensitive plant organs (buds, leaves, flowers) to more frequent spring and autumn frost events (Cannell and Smith, 1986; Liu et al., 2018; Ma et al., 2018). In fact, 43\% of the Northern Hemisphere has experienced an increase of more than one growing-season frost event per year over the period 1982-2012 (Liu et al., 2018). In addition, climate warming (both mean and extremes) is not equal across seasons and latitudes (Loarie et al., 2009; Brown, 2019). Winter and spring are warming faster than summer and autumn and the frequency and intensity of extreme climatic events such as heavy rainfall and droughts are rising (Easterling et al., 2000; Stott et al., 2015; Brown, 2019). Therefore, the response of trees to climate change will likely diverge across stands or populations of the same species (D'Orangeville et al., 2018; Marchand et al., 2019), increasing the need for populationspecific response to climate change. However, these responses to climate change at the population level remain largely unknown, which stresses the importance of quantifying local adaptations to better forecast the fitness of forest tree species.

At the tree level, spring frosts damage both apical and cambial meristems, as well as the leaves, thereby reducing tree growth and altering tree architecture (Clements et al., 1972; Dy and Payette, 2007; Augspurger, 2009). In contrast, summer frosts can delay the formation of the following year's foliage by damaging the newly developed primordia of evergreen trees or by limiting nutrient resorption from damaged leaves in deciduous trees (Estiarte and Peñuelas, 2015). At the ecosystem level, frost damage to leaves can decrease net primary productivity of the forests (Hufkens et al., 2012).

The frequency and intensity of spring frosts are hard to predict, given their rare occurrence and dependency upon terrain complexity (Laughlin and Kalma, 1987; Lindkvist and Lindqvist, 1997; Chung et al., 2006), where cold air masses can be trapped in topographic depressions resulting in localized frost pockets across the landscape (Dy and Payette, 2007). The strong effects of spring frosts on the fitness of temperate and boreal plant species make them important drivers of species range limits (Inouye, 2008; Kollas et al., 2014; Körner et al., 2016; Du et al., 2019). Yet spring frost effects upon spring phenology have seldom been studied (Körner et al., 2016; Lenz et al., 2016). Furthermore, these later frosts have been excluded from ecophysiological models predicting leaf-out dates, thereby favoring the use of aggregated metrics such as growing degree-days (GDDs) and photoperiod (Fuchigami and Nee, 1987; Chuine, 2000; Hänninen, 2006; Linkosalo et al., 2006). Given the high daily variation that is observed for air temperature, the more predictable nature of night/ day length would make photoperiod a more reliable environmental cue for preventing early dormancy release or late dormancy entrance (Partanen et al., 1998; Cooke et al., 2012; Soolanayakanahally et al., 2013; Lang et al., 2019). However, sensitivity to photoperiod varies between species and with successional status (Caffarra and Donnelly, 2011; Basler and Körner, 2012). Therefore, disentangling the relative effects that air temperature variables (growing degree-days vs. spring frosts) and photoperiod exert on the physiological processes driving tree growth is critical to better forecast climate change effects on the productivity of temperate and boreal species.

One of the best scientific records for analyzing environmental drivers of the dormancy-growth cycle of trees is the phenological observation of bud burst in spring and bud set in autumn, since these events determine the start and the end of the growing season (Aono and Kazui, 2008; Hänninen, 2016; Tang et al., 2016). Unfortunately, the performance of many ecophysiological models that have been implemented to predict the dates when buds are expected to break is under debate because: (1) no single model provides the best fit for all tree species and (2) different models using various combinations of climate and photoperiod variables lead to similar prediction of bud break dates (Basler, 2016). Therefore, the important environmental variables triggering the physiological mechanisms of bud burst cannot be identified. This discrepancy in model projections may be the results of methodological oversimplification in the input bud phenology data or the omission of significant air temperature variables, such as spring frost occurrence. In fact, the bud break sequence must be synchronized with the decrease in frost days during spring otherwise trees would recurrently be damaged by spring frosts. However, a late bursting of the buds would decrease the growing season length, potentially decreasing growth and losing competition for space, light and nutrients to trees bursting buds earlier. Thus, the bud break sequence first follows a frost avoidance trade-off followed by a rapid bud burst that maximizes the growing season length. Consequently, the various phenological stages of the bud break process might respond to different environmental cues. However, little is known about these ecological strategies driving the bud break sequence because bud phenology is traditionally analyzed using scattered discrete field observations of buds in spring, of which, only one phenological stage (the phenological stage where buds break) is analyzed, omitting the possibility that the sensitivity of buds to environmental cues may vary within the continuous process of bud break (Hannerz, 1999; Snyder et al., 1999; Polgar and Primack, 2011). 
The objectives of our study were to identify the environmental drivers at each stage of the bud break process on three spruce species and various seed sources with different bud flushing dates in two plantations that were established in the northern temperate forest and in the boreal mixedwood forest of western Quebec (Canada). In each plantation, we expected that the white spruce (Picea glauca [Moench] Voss) would flush its buds earlier than both the black spruce (Picea mariana [Mill.] B.S.P.) and the Norway spruce (Picea abies [L.] Karst.). At the intraspecies level, we expected that in the boreal mixedwood plantation, the southern seed sources (from the temperate forest) would open their buds earlier than the local seed source (from the boreal mixedwood forest), which would increase their exposure to spring frosts and prove to be disadvantageous to early plantation productivity during years of these occurrences. For the environmental drivers of the bud break process, we expected that as long as needles are protected by the bud scales (phenological stages 0-3), the minimum air temperature and the day length would be the main environmental drivers of transition from one stage to the next. Once needles are exposed to variation in ambient air temperature (phenological stages 4-6), subsequent bud transitions would be driven by growing degreedays. We further expected that the seed source originating from the boreal mixedwood forest would better synchronize its bud break timing with frost probability compared to nonlocal seed sources.

\section{MATERIALS AND METHODS}

\section{Study Site}

Our study was conducted in two experimental plantations containing white spruces, black spruces, and Norway spruces. The two plantations were established in 2002; one in the northern temperate forest and one in the boreal mixedwood forest of the northern Clay Belt of Quebec (Figure 1). Mean annual temperature at the temperate forest plantation site $\left(47.29^{\circ} \mathrm{N} ; 79.12^{\circ} \mathrm{W}\right)$ is on average $2.1^{\circ} \mathrm{C}$ higher than at the boreal mixedwood forest plantation site $\left(48.29^{\circ} \mathrm{N} ; 79.26^{\circ} \mathrm{W}\right)$, with a mean annual temperature of $3.1^{\circ} \mathrm{C}$ and mean monthly

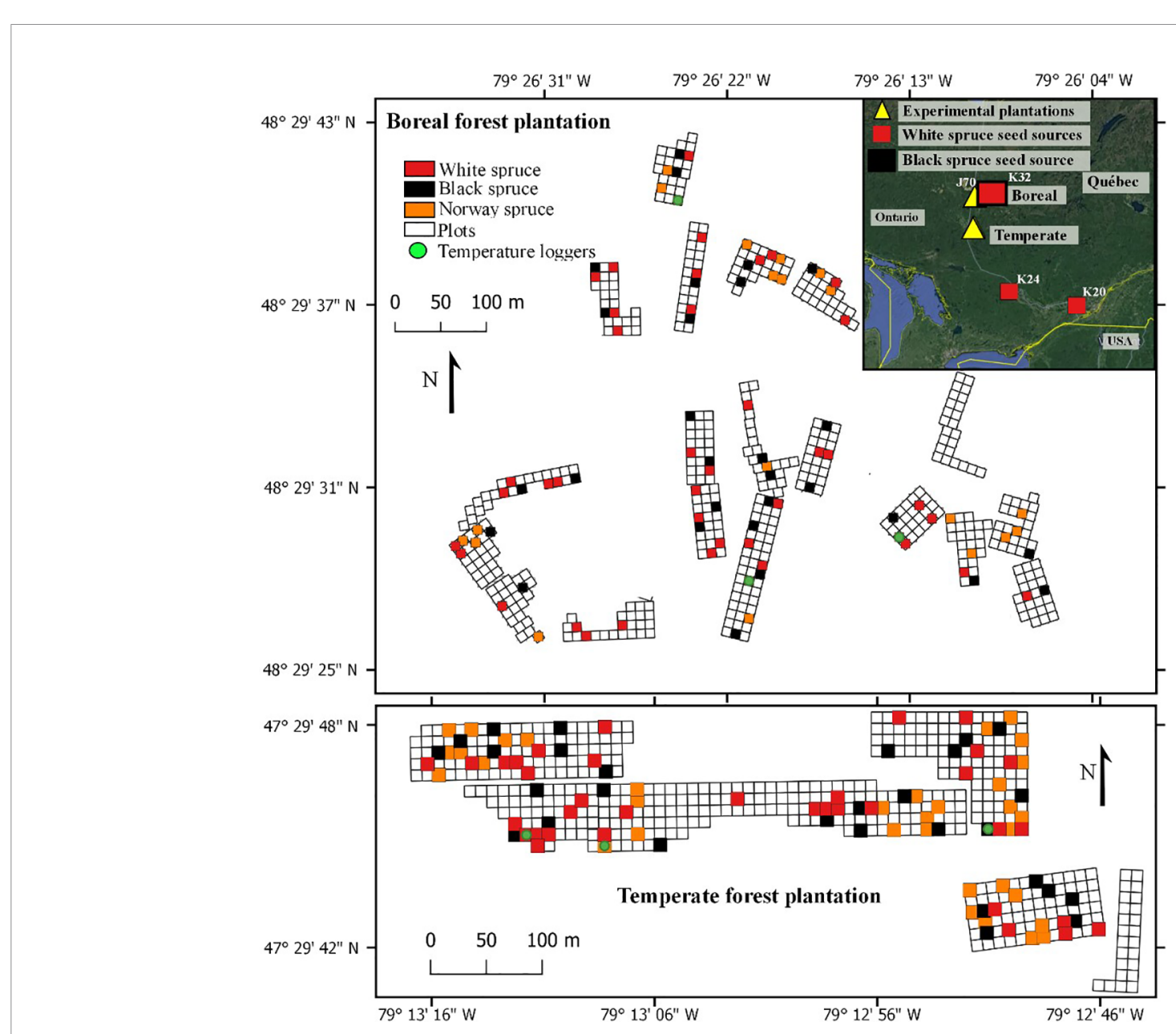

FIGURE 1 | Experimental design of the plantations, the randomly sampled plots (colored squares) that were used for this study, and locations of air thermometer at the boreal mixedwood forest plantation (top) and at the temperate forest plantation (bottom). Inset shows the locations of the temperate forest and boreal mixedwood forest plantations, together with the North American seed sources. 
temperatures of $-15.0^{\circ} \mathrm{C}$ and $18.8^{\circ} \mathrm{C}$ in January and July, respectively (1981-2010 Normals, Barrage Angliers weather station located $24 \mathrm{~km}$ from the temperate forest plantation site, Environment Canada, 2019a) compared to a mean annual temperature of $1.0^{\circ} \mathrm{C}$ and mean monthly temperatures of $-17.9^{\circ} \mathrm{C}$ and $16.7^{\circ} \mathrm{C}$ in the boreal mixedwood forest in January and July, respectively (1981-2010 Normals, Mont-Brun weather station located $47 \mathrm{~km}$ from the boreal mixedwood forest plantation site, Environment Canada, 2019b). At the temperate forest plantation site, the frost-free period is 46 days longer than at the boreal mixedwood forest plantation site, starting earlier by 21 days (May 24 ${ }^{\text {th }}$, [DOY 144] vs. June 13 ${ }^{\text {th }}$, [DOY 164]), and ending 25 days later (September $24^{\text {th }}$, [DOY 267] vs. August $31^{\text {st }}$, [DOY 243]). The last growing-season frost ( 0.10 probability that air temperature $<0^{\circ} \mathrm{C}$ ) at the boreal mixedwood forest plantation site usually occurs 19 days later than in the temperate forest plantation site (June $15^{\text {th }}$, [DOY 166] vs. July $4^{\text {th }}$, [DOY 185]; 1981-2010 Normals, Barrage Angliers and Mont-Brun weather stations, Environment Canada, 2019a; Environment Canada, 2019b). These spring frosts mostly result from the temperature inversion phenomenon which generates nighttime near-ground frost events lasting few hours (Dugas, 1975; Laughlin and Kalma, 1987), which can damage both the buds and the cambium of small trees such as trees in young plantations (Dy and Payette, 2007). Precipitation is similar in the two plantation sites: the total rainfall is $709 \mathrm{~mm}$ vs. $705 \mathrm{~mm}$ and the total snowfall is 2580 vs. $2810 \mathrm{~mm}$ for the temperate forest and boreal mixedwood forest plantation sites, respectively. Day length in the temperate forest plantation site was eight minutes shorter during summer and eight minutes longer during winter compared to the boreal mixedwood forest plantation site (Sunset calculator, Environment Canada, 2019c).

\section{Experimental Design}

The plantations consisted in 480 square plots of $64 \mathrm{~m}^{2}$ and each plot was randomly assigned to a white spruce seed sources (20 seed sources tested), a Norway spruce seed source (20 seed sources tested) or a black spruce seed source (1 seed source tested). In each plot, 25 trees of the same seed source were planted with a $2 \mathrm{~m}$ by $2 \mathrm{~m}$ spacing in five rows of five. The 20 different white spruce seed sources were collected from a firstgeneration seed orchard established in Cap-Tourmente in 1981 $\left(47.06^{\circ} \mathrm{N}, 70.45^{\circ} \mathrm{W}\right)$, the 20 Norway spruce seed sources were collected from a plantation established in 1969 in Valcartier Forest Experiment Station $\left(46.56^{\circ} \mathrm{N}, 71.30^{\circ} \mathrm{W}\right)$ for an international project on Norway spruces coordinated by the International Union of Forest Research Organizations (IUFRO) (Blouin et al., 1994; Matras, 2002). The two plantations were designed to compare the development of trees between local vs. nonlocal seed sources and to test for geneticbased adaptations and phenotypic plasticity by planting each seed sources in two contrasting climate regimes (the northern temperate forest and the boreal mixedwood forest) at the borealtemperate forest ecotone of western Quebec (see Figure S1 for species range maps, location of the seed sources, location of the seed orchards and the location of the plantation sites). Both local black and white spruce seed sources from the boreal mixedwood forest were used as controls. To quantify inter- and intraspecies variation in the timing of bud break, the 20 seed sources for white and Norway spruce were split into four quartiles based upon tree heights that were previously measured in 2012; one seed source per quartile was randomly selected for bud observation. For the white spruce, most trees from the lower quartile were dead at the boreal mixedwood forest plantation site. Therefore, only three seed sources (quartiles 2 to 4 ) were selected (see Table 1 for the geographic locations of seed sources that were used in our study and see Table 2 for a description of the climate at their location of origin). Only one black spruce seed source was studied because the black spruce usually flushes its buds late compared to the white spruce and, therefore, the black spruce represents a reliable benchmark for determining the impact of spring frosts on bud phenology. We avoided plots where trees were infested by the

TABLE 1 | Number of trees monitored, bud observations and median day of year of budbreak (phenological stage 5) per species, seed source, tree height quartile, and plantation site.

\begin{tabular}{|c|c|c|c|c|c|c|c|c|}
\hline \multirow{2}{*}{$\begin{array}{l}\text { Spruce } \\
\text { species }\end{array}$} & \multirow{2}{*}{$\begin{array}{c}\text { Seed source } \\
\text { (height } \\
\text { quartile) }\end{array}$} & \multirow[t]{2}{*}{ Latitude } & \multirow[t]{2}{*}{ Longitude } & \multirow[t]{2}{*}{ Locality } & \multicolumn{2}{|c|}{ Temperate forest plantation } & \multicolumn{2}{|c|}{ Boreal mixedwood forest plantation } \\
\hline & & & & & $\begin{array}{l}\text { Number of trees } \\
\text { (buds) }\end{array}$ & $\begin{array}{c}\text { Median day of } \\
\text { budbreak }\end{array}$ & $\begin{array}{c}\text { Number of trees } \\
\text { (buds) }\end{array}$ & $\begin{array}{l}\text { Median day of } \\
\text { budbreak }\end{array}$ \\
\hline Norway & K35 (Q4) & $55.15^{\circ} \mathrm{N}$ & $30.10^{\circ} \mathrm{E}$ & Glubokskii, Belarus & $12(601)$ & 165 & $5(190)$ & 164 \\
\hline Norway & K39 (Q3) & $49.33^{\circ} \mathrm{N}$ & $18.52^{\circ} \mathrm{E}$ & Istebna, Poland & $13(619)$ & 165 & $2(68)$ & 162 \\
\hline Norway & K50 (Q1) & $55.30^{\circ} \mathrm{N}$ & $30.00^{\circ} \mathrm{E}$ & Gorodokskii, Belarus & $15(740)$ & 158 & $4(149)$ & 164 \\
\hline \multirow[t]{2}{*}{ Norway } & K55 (Q2) & $56.25^{\circ} \mathrm{N}$ & $22.50^{\circ} \mathrm{E}$ & Auce, Latvia & $13(697)$ & 155 & $6(211)$ & 155 \\
\hline & & Total & & & $53(2657)$ & & $17(618)$ & \\
\hline White & J70 (Q4) & $48.29^{\circ} \mathrm{N}$ & $79.26^{\circ} \mathrm{W}$ & Duparquet, Québec & $27(1176)$ & 155 & $27(1026)$ & 157 \\
\hline White & K20 (Q2) & $45.36^{\circ} \mathrm{N}$ & $74.28^{\circ} \mathrm{W}$ & Cushing, Québec & $15(727)$ & 155 & $8(320)$ & 156 \\
\hline \multirow[t]{2}{*}{ White } & K24 (Q3) & $45.54^{\circ} \mathrm{N}$ & $77.20^{\circ} \mathrm{W}$ & Petawawa, Ontario & $13(557)$ & 151 & $13(247)$ & 153 \\
\hline & & Total & & & $55(2460)$ & & $48(1593)$ & \\
\hline \multirow[t]{2}{*}{ Black } & K32 & $48.29^{\circ} \mathrm{N}$ & $79.26^{\circ} \mathrm{W}$ & Duparquet, Québec & $51(2357)$ & 165 & $34(1215)$ & 164 \\
\hline & & $\begin{array}{l}\text { Grand } \\
\text { total }\end{array}$ & & & $159(7474)$ & & 99 (3426) & \\
\hline
\end{tabular}


white pine weevil (Pissodes strobi). For the remaining plots, stratified randomly sampling was performed to select 185 plots, which were distributed across species and seed sources.

\section{Bud Phenology Observations}

Each bud observation was classified into one of the seven bud break stages (0-6). The stages were described by Dhont et al. (2010) for white spruce buds, by Numainville and Desponts (2004) for black spruce buds, and by Sutinen et al. (2012) for Norway spruce buds. To maintain the same number of stages per species, we added one last stage to Norway spruce, i.e., needles elongating and expanding laterally (Table 3). Buds were observed weekly from May $10^{\text {th }}$ until leaf-out (see Figure S2 for the precise sampling dates). This sampling time interval was based upon previous studies analyzing bud phenology (Clark et al., 2014a; Perrin et al., 2017) and because of logistical constraints (large distance between both plantation sites) that prevented observing bud phenology at a shorter time interval. The average time delay between bud observations at one plantation and bud observations at the other plantation was of only two to three days. Even if our sampling time interval could have led to missing observations for given phenology stages, the large amount of observations collected over 258 trees increases the robustness of our data and analyses compared to more frequent bud observations collected over a limited number of individuals. The apical bud could not be observed since trees were too tall. Therefore, the terminal buds of all branches belonging to the whorl at breast height (from two to six buds per tree) were followed for two consecutive years (2016-2017). In total, 10900 buds were observed over 258 trees (Table 1). Since stages one and two closely resemble one another, they were difficult to identify in the field. Therefore, data were merged for these two stages.

\section{Climate Variables Used to Predict Timing of Bud Break}

To analyze the timing of bud break in relation to in situ air temperature, we installed three thermometers (iButton
DS1922L, measurement accuracy of $\pm 0.5^{\circ} \mathrm{C}$, Maxim Integrated, San Jose, CA, USA) per plantation site set to record air temperature every $30 \mathrm{~min}$ from snow melt in the spring to August for two consecutive years (2016-2017). We averaged the data from the three thermometers to create one daily temperature record per site. Due to the presence of snow on the ground at the time of the first bud observations, thermometers were set 13 days later, once snow had melted. The missing air temperature data from onsite measurements were supplemented using the following approach: we used the BioSIM 10 software that was developed by Natural Resources Canada (Régnière et al., 2014) to simulate daily air temperature by accounting for elevation and aspect at both plantation sites for the entire growing season. For each plantation and temperature logger, we then regressed the air temperature that was measured in the field against the simulated air temperature values. All linear regressions were significant $(P$-values $<0.05)$. The mean adjusted $R^{2}$ of all linear regressions was 0.86 , being higher for mean temperature $\left(R^{2}=0.92\right)$ and lower for minimum $\left(R^{2}=0.82\right)$ and maximum temperature $\left(R^{2}=0.85\right.$; Tables S1 and S2). Using the regression coefficients, we predicted the minimum, mean and maximum daily air temperature for the 13 missing days per data logger. We then averaged these predicted values per plantation and incorporated them into our observed air temperature dataset (Figure 2A). To determine which temperature variable best predicted each phase of the bud break process, we tested the minimum, mean and maximum daily air temperature, the sum of growing degree-days above $0^{\circ} \mathrm{C}$, starting January $1^{\text {st }}$, which were calculated with the maximum daily air temperature (GDD $\max$ ), and the mean daily air temperature (GDD mean; Figure 2B). We also analyzed the daily probability of occurrence of a frost event, which was calculated from the binomial regression analysis of the frequency of frost events. Days where minimum daily air temperature was below $0^{\circ} \mathrm{C}$ were coded 1 and the others, 0 (Figure 2C). We also analyzed the impact of photoperiod on bud phenology by retrieving the day length (hours of

TABLE 2 | Climate normals (1981-2010) at the location of origin of each nonlocal seed source.

\begin{tabular}{|c|c|c|c|c|c|c|c|}
\hline $\begin{array}{l}\text { Seed source } \\
\text { (locality) }\end{array}$ & $\begin{array}{l}\text { Weather station } \\
\text { (distance to } \\
\text { locality) }\end{array}$ & $\begin{array}{l}\text { Mean annual } \\
\text { temp. in }{ }^{\circ} \mathrm{C}\end{array}$ & $\begin{array}{l}\text { Mean January temp. } \\
(\min ; \max ) \text { in }{ }^{\circ} \mathrm{C}\end{array}$ & $\begin{array}{l}\text { Mean July temp. } \\
\left(\text { min; max) in }{ }^{\circ} \mathrm{C}\right.\end{array}$ & $\begin{array}{l}\text { Precipitation } \\
\text { sum in mm }\end{array}$ & $\begin{array}{c}\text { Growing } \\
\text { degree-days } \\
\text { (base temp. } \\
0^{\circ} \mathrm{C} \text { ) }\end{array}$ & $\begin{array}{l}\text { Date with } 0.10 \\
\text { probability of frost in } \\
\text { spring (DOY) }\end{array}$ \\
\hline $\begin{array}{l}\text { K35 } \\
\text { (Glubokskii) }\end{array}$ & Smolensk (130 km) & 5.5 & $-6.2(-33 ; 9)$ & $17.8(5 ; 35)$ & 738 & 2.713 & May $11^{\text {th }}(131)$ \\
\hline $\begin{array}{l}\mathrm{K}^{\mathrm{K}} 39^{1} \\
\text { (Istebna) }\end{array}$ & Bielsko-Biala (33 km) & 8.5 & $-1.3(-27 ; 15)$ & $18.0(4 ; 34)$ & 944 & 3.365 & May $5^{\text {th }}(125)$ \\
\hline $\begin{array}{l}\mathrm{K} 55^{1} \\
\text { (Auce) }\end{array}$ & Siauliai (62 km) & 6.8 & $-2.8(-32 ; 11)$ & $17.8(6 ; 35)$ & 614 & 2.904 & May $17^{\text {th }}(137)$ \\
\hline $\begin{array}{l}\mathrm{K}^{2} \mathrm{O}^{2} \\
\text { (Cushing) }\end{array}$ & Lachute (12 km) & 6.0 & $-10.7(-37 ; 11)$ & $20.4(4 ; 35)$ & 1.151 & 3.177 & May $27^{\text {th }}(147)$ \\
\hline $\begin{array}{l}\text { K24 } \\
\text { (Petawawa) }\end{array}$ & Sheenboro (10 km) & 5.0 & $-12.1(-39 ; 11)$ & $19.3(1 ; 40)$ & 853 & 2.972 & June $10^{\text {th }}(161)$ \\
\hline
\end{tabular}

${ }^{1}$ Climate data for European seed sources were retrieved from the KNMI Climate Explorer (European Climate Assessment \& Data) https://climexp.knmi.nl/start.cgi.

${ }^{2}$ Climate data for Canadian seed sources were retrieved from Environment Canada (Climate normals) https://climate.weather.gc.ca/climate_normals/. 
TABLE 3 | Development stages of the spring bud phenology of white spruce (Dhont et al., 2010, p. 9), black spruce (Numainville and Desponts, 2004, pp. 10-16, Figs 6B, 7B, 8B, 9B, 10B, 11A, 12A.) and Norway spruce (Sutinen et al., 2012, p. 990, Figure 2).

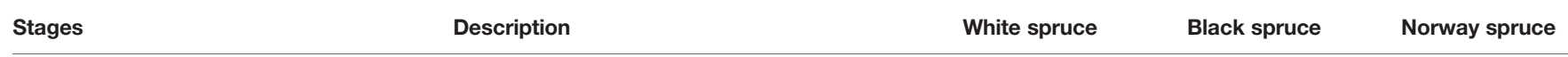

$0 \quad$ Buds are closed and dormant.

1 Bud scales are opening, and from an apical view, a white spot is visible at the top of the bud.

Buds are elongating

Buds are swelling.

Bud scales are translucent, and the needles are partly visible.

Bud scales are ripped at the base of the bud (white and black spruce) or open at the top (Norway spruce), and needles are tightly bundled.
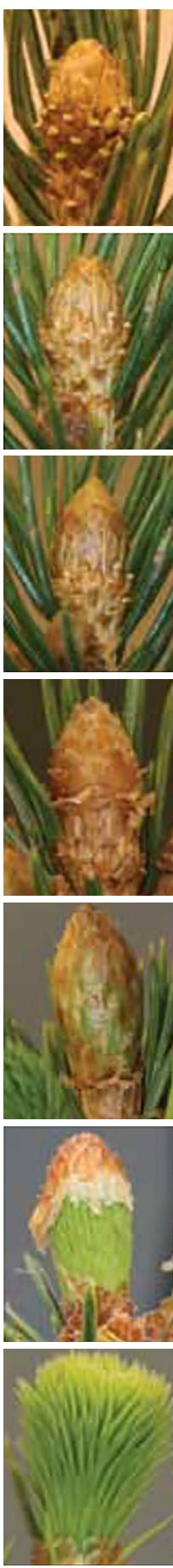
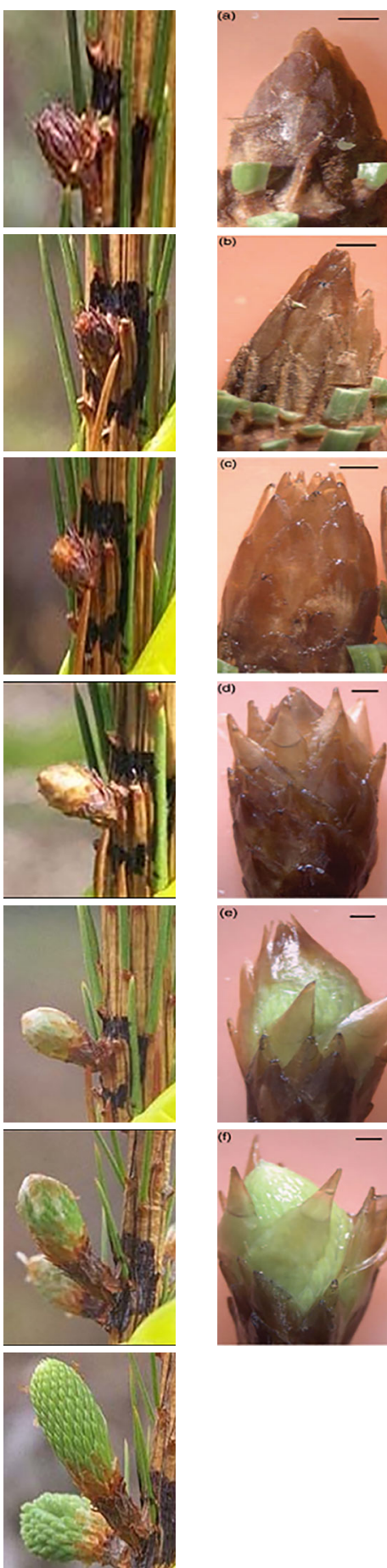
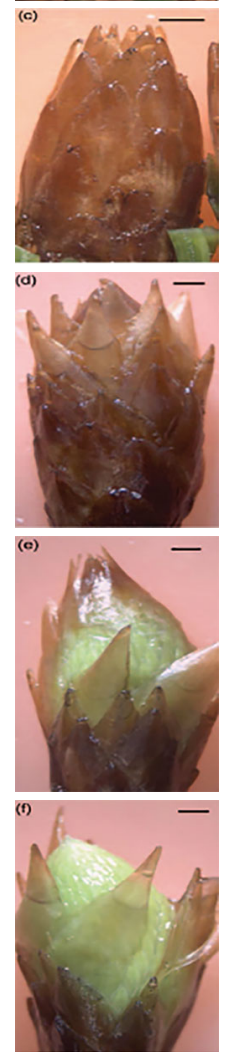

No photograph showing buds of the Norway spruce in stage six was available. 

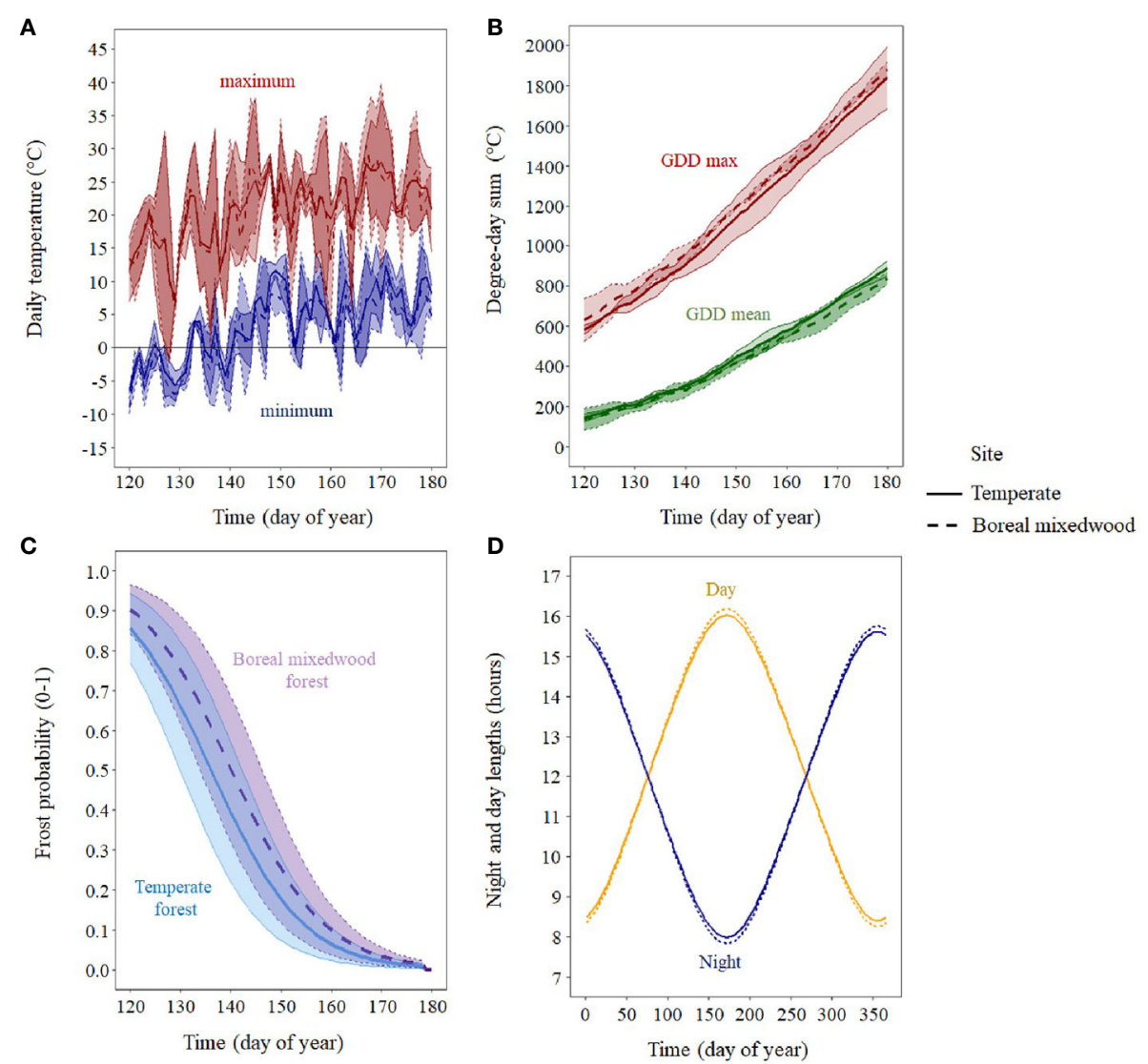

FIGURE 2 | Mean (line) and standard error (shaded area) for the period 2016-2017 for air temperature and photoperiod variables that were tested: (A) mean daily minimum and mean daily maximum temperature; (B) sum of growing degree-days calculated with mean and maximum temperature; (C) probability of a frost event per site; and (D) night and day length in hours.

illumination during the day) from the sunset calculator (Environment Canada, 2019c) for both plantation sites (Figure 2D).

\section{Statistical Methods}

Prior to all analyses, numerical variables were standardized to allow comparison of the strength of coefficients from different variables. Bud observations consist in a series of stages linked by time since buds can only transit from one stage to the next. Therefore, we separately analyzed the five transitions $(0->2 ; 2-$ $>3 ; 3->4 ; 4->5 ; 5->6$ ) with a binomial model, using 0 s for buds that remained in their current stage and $1 \mathrm{~s}$ for buds that were transitioning to the next stage, a method also used by Perrin et al. (2017) (Figure 3). The site, species or seed sources, and their interactions were analyzed as fixed effect terms, whereas years and tree identity were incorporated into the random structure of the binomial regression model. We implemented these models in $\mathrm{R}$ using the glmer function with the bobiqa optimiser algorithm from the lme4 package (Bates et al., 2015). We considered that a bud would transit to the next stage of bud phenology once the transition probability was 0.51 . We quantified bud break duration by subtracting the day of year where the transition probability of reaching stage six in the bud phenology was 0.51 from the day of the year where the transition probability of reaching combined stages one and two was also 0.51 . We acknowledge that by merging stages one and two, we had underestimated the duration of the bud break process.

To determine which air temperature and photoperiod variables best predicted each phenological transition per species, we defined 31 air temperature models (Table S3) and six photoperiod models (Table S4), including a null model testing the occurrence of bud flush according to time only. This last model included day-of-year (DOY) as the predictor variable. We compared candidate models against the null using model selection, which evaluated model fit with the corrected Akaike's information criteria (AICc) (R package AICcmodavg; Mazerolle, 2017). If model selection failed to identify one best model, we used multi-model inference to average the coefficients in each probable model using the model.avg function from the $\mathrm{R}$ package MuMIn (Barton, 2018). To limit multicollinearity problems because of correlated climate variables and high $(>10)$ variance inflation factors when two environmental 


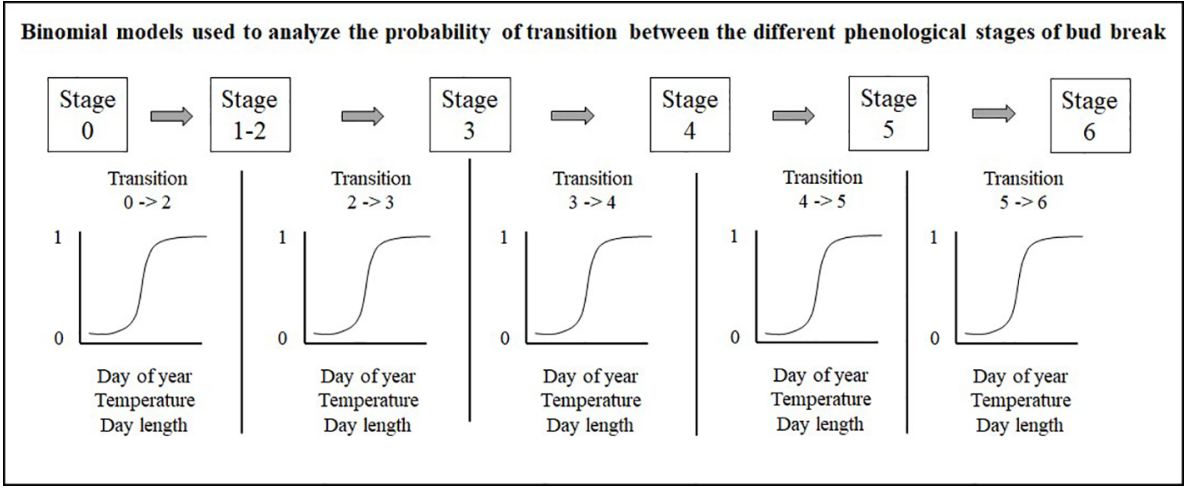

FIGURE 3 | Mixed binomial regression models analyzing the probability of transition between the different phenological stages of bud break.

variables co-occurred in a same model, we only tested models with single climate variables in various combinations with species, sites, and their two-way interactions. Since photoperiod and air temperature can interact to affect bud break timing (Rossi and Isabel, 2016), we first performed model selection to identify the best air temperature model per transition. We performed a second model selection to identify the best photoperiod model per transition. We then compared the best air temperature model to the best photoperiod model by analyzing the strength of their regression coefficients. Since statisticians still debate on how to properly calculate statistical significance of coefficients when regression analyses include a random structure, we considered a variable to be statistically significant if the error around the coefficient did not include zero. Once the best climate variables were identified per stage of bud phenology, we analyzed intraspecies variation in bud phenology by adding the seed source.

We restricted our analyses to the observed sequence of bud flush in spring only instead of using a dynamic model considering the interplay between spring warming and chilling requirement in autumn to model the dehardening process because 1) values for the chilling requirement were not available at the seed source level; 2) a previous study showed that the chilling requirement for spruce species were low (300500 chilling hours) compared to other boreal and temperate tree species (trembling aspen requires 1100 chilling hours) and were completed by the end of December (Man et al., 2017), therefore unlikely impacting bud break timing in spring; and 3) we gathered bud flush data for only two years. For the latter, the possibility that warmer autumn decreases the number of accumulated chilling units in autumn, thus postponing chilling completion to early spring and consequently delaying bud break is limited compared to long-term bud phenology studies using dynamic models. Hence, the importance of chilling temperatures in controlling bud flush phenology in the spring was less of a concern in our study.

To show how our bud phenology data compared with the more conventional bud phenology analyses, we compared the sum of growing degree-days above $0^{\circ} \mathrm{C}$ that was required for buds to open (phenological stage five; Table 3) per species and site with previously published results (Snyder et al., 1999; Man and Lu, 2010).

\section{RESULTS}

\section{Inter- and Intraspecies Variation in the Timing of Bud Break}

Results for the timing of bud break are based upon forecasts from the mixed binomial regression models predicting on which dayof-year (DOY) the transition probability was 0.51 . For the white spruce, the black spruce and the Norway spruce, bud break in the temperate forest plantation was completed in 16, 23, and 15 days, respectively, compared to 19,19 , and 17 days in the boreal mixedwood forest plantation (Figures 4 and 5). The black spruce was the only species for which bud break phenology was faster in the boreal mixedwood forest than in the temperate forest. At both plantation sites, the white spruce reached each bud phenology stage the earliest. Also, at both plantation sites, interspecies variations were the highest for the bud swelling stage (stage three, see Table 3 ). For instance, the white spruce was the earliest species to swell buds (when the frost probability was of 0.31 and 0.33 at the temperate forest and at the boreal forest respectively) whereas both the black spruce and the Norway spruce swell buds when the frost probability was $20 \%$ and $23 \%$ lower at the temperate forest and the boreal forest respectively (Figure 5).

At the intraspecies level, the nonlocal southern white spruce seed sources K20 and K24 reached each phenological stage of the bud break process earlier than the local seed source J70 (Figures 4 and $\mathbf{6}$ and Table 5). In the temperate forest, white spruce intraspecies variations were the highest for the bud swelling stage (stage four). For instance, exposure to spring frost was $12 \%$ higher (from a probability of 0.41 to 0.29 ) for the southern seed sources compared to the local seed source originating from the boreal mixedwood forest. In the boreal mixedwood forest, white spruce intraspecies variations were highest for the translucent bud scales stage. For instance, exposure to spring frost was $10 \%$ 

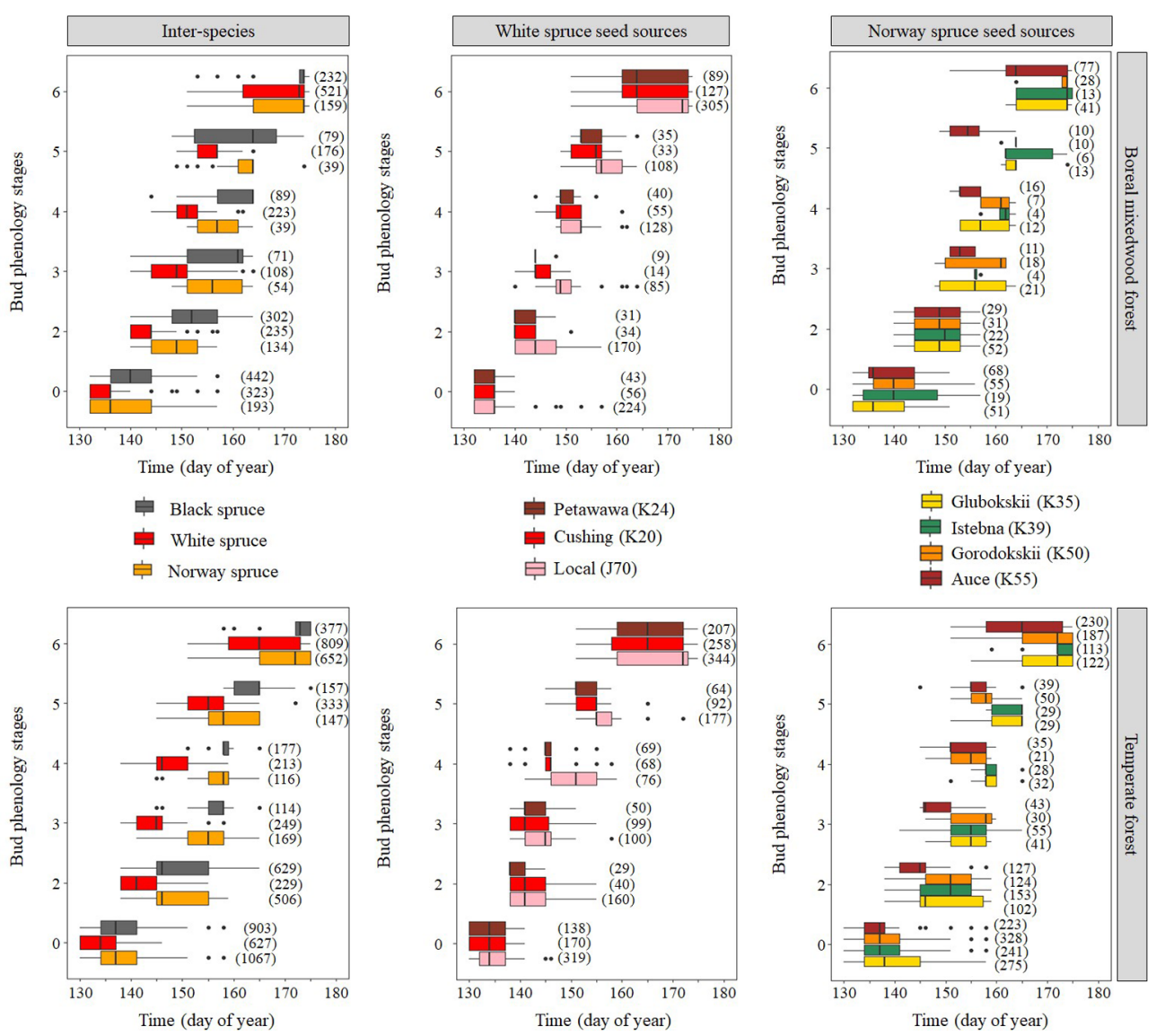

FIGURE 4 | Observed distribution (box plots) of the phenological stages with time showing both inter- and intraspecies variations in the bud break process. The boxes show the $25^{\text {th }}$ and $75^{\text {th }}$ percentiles, and the line inside each box represent the median. The number in parenthesis shows the number of observations per phenological stage, species, and site.

higher (from a probability of 0.33 to 0.23 ) for the southern seed sources compared to the local seed source originating from the boreal mixedwood forest, which flushed its buds the latest (Table 5).

For the Norway spruce, at both sites, the first and the last seed source to complete bud flush were the K55 and K39 respectively. Important differences in bud break timing were observed for intermediate bud phenology stages. Bud swelling occurred on average 7 days and 12 days earlier for the K55 seed source in the temperate forest and in the boreal mixedwood forest respectively when compared to the K39 seed source. These differences in timing of bud break increased exposure to spring frost by $7 \%$ (from a probability of 0.16 to 0.09 ) in the temperate forest and by $21 \%$ (from a probability of 0.33 to 0.12 ) in the boreal mixedwood forest (Figures 4 and 7 and Table 6).

\section{Interspecies Variation in the Effects of Air Temperature and Photoperiod for Predicting Bud Break Phenology}

Model selection on the 31 air temperature candidate models produced from one to three statistically plausible models (5\%) for each stage transition (Figure 8 and Tables S5-S9 for complete results of the AICc model selection per stage transition). The average marginal pseudo- $R^{2}$ was $0.47 \pm 0.15$ and the conditional pseudo- $R^{2}$ was $0.84 \pm 0.06$ for the selected models. Here, the marginal value of $R^{2}$ represents the variance that was explained by the fixed effects, while the conditional value represents the variance that was explained by both fixed and random effects (Barton, 2018). The null model for bud flush solely as a function of time was always rejected (Tables S5 to S9). Phenological stages where needles were still protected by the bud scales [bud elongation to bud swelling (stages two and three), see Table 3] were best predicted by the probability of spring frost occurrence whereas growing degree-days best predicted dates that buds reached phenological stages where needles were exposed to air temperature (stages four to six) (Figure 8).

Sensitivity to air temperature (both spring frost occurrence and GDDs) varied among species and sites (Table 4 and Tables S10-S14 for the coefficients of each climate variable per stage transition). Specifically, the white spruce was more sensitive to both the probability of spring frost occurrence and the growing degree-days compared to either the black spruce or the Norway spruce. The probability of spring frost occurrence was more important for predicting transition probabilities of buds in the 

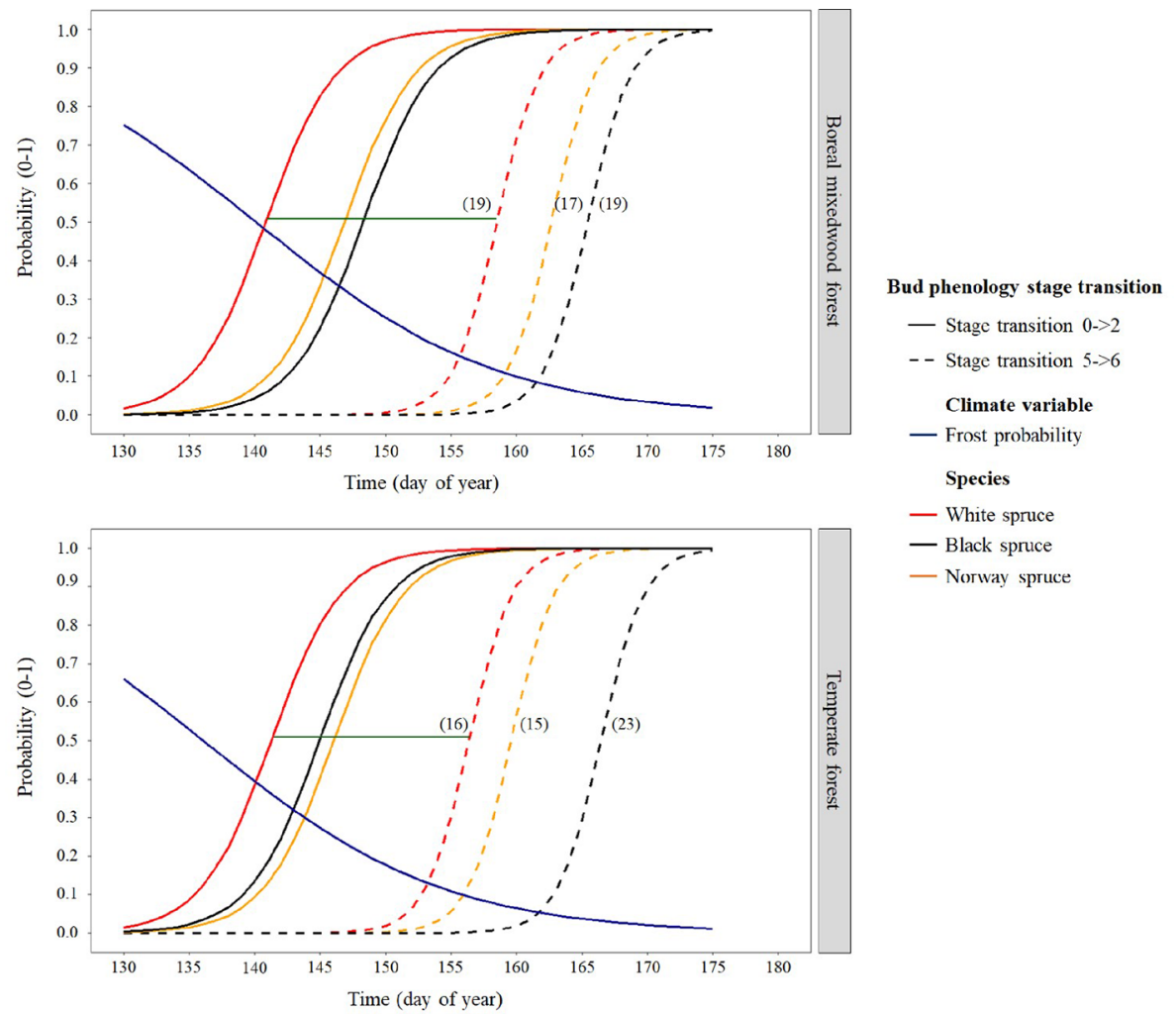

FIGURE 5 | Interspecies variation in bud break timing showing the transition probabilities between the first and last transition stages of bud phenology per species, plantation site, and frost probability with time. The horizontal green line shows the duration of the bud break process for white spruce and the numbers in parentheses show the duration (in days) of the bud break process per species and site.

boreal mixedwood compared to the temperate forest. In contrast, growing degree-days were more important for predicting transition probabilities of buds in the temperate forest plantation, particularly for the transition from phenological stage four to five (Table 4 and Tables S10-S14).

Model selection on the six candidate photoperiod models produced from one to two statistically plausible models (5\%) for each stage transition (Figure 8 and Tables S15-S19 for complete results of the AICc model selection per transition stage). The average marginal pseudo- $R^{2}$ (i.e., fixed effects) was $0.50 \pm 0.09$, while the conditional pseudo- $R^{2}$ (i.e., fixed plus random effects) was $0.83 \pm 0.08$ for the selected models. The null model that tested the occurrence of bud flush solely as a function of time was rejected for the first four transitions but was the most probable model for predicting the last transition (Figure $\mathbf{8}$ and Tables S15-S19). Thus, sensitivity to photoperiod was important for the first and intermediate phenological stages only. Sensitivity to photoperiod was the highest for the white spruce, followed by the Norway spruce and by the black spruce, and was higher in the temperate plantation compared to the boreal mixedwood plantation (Table 4, Tables S10-S14).

The probability of spring frost occurrence was slightly more important in predicting bud elongation (stage 2) compared to photoperiod (Table S10). Growing degree-days and photoperiod had a similar importance in terms of predicting intermediate phenological stages (bud swelling and translucent bud scales), whereas growing degree-days were more important than photoperiod for predicting the completion of the bud break process (Tables S10 to S14). Overall, the white spruce required shorter day lengths, fewer growing degree-days, and opened its buds under higher frost probabilities than did either the black spruce or the Norway spruce (Table 4).

\section{Intraspecies Variations in the Effect of Air Temperature and Photoperiod for Predicting Bud Break Phenology}

Buds of white spruce seed sources K20 and K24 from the temperate forest were more sensitive to photoperiod for phenological stages two (bud elongation, see Table 3) to five (bud scales ripped and needles exposed to air temperature), were more sensitive to spring frost occurrence for the phenological stages two (bud elongation) and three (bud swelling), and were more sensitive to growing degree-days for phenological stages four (translucent bud scales), five (bud scales ripped and needles exposed to air temperature), and six (complete bud flush) compared to the seed source J70 originating from the boreal mixedwood forest (Table 5 and Tables S20 to S24). Therefore, white spruce seed sources from the temperate forest required shorter day lengths, fewer growing 


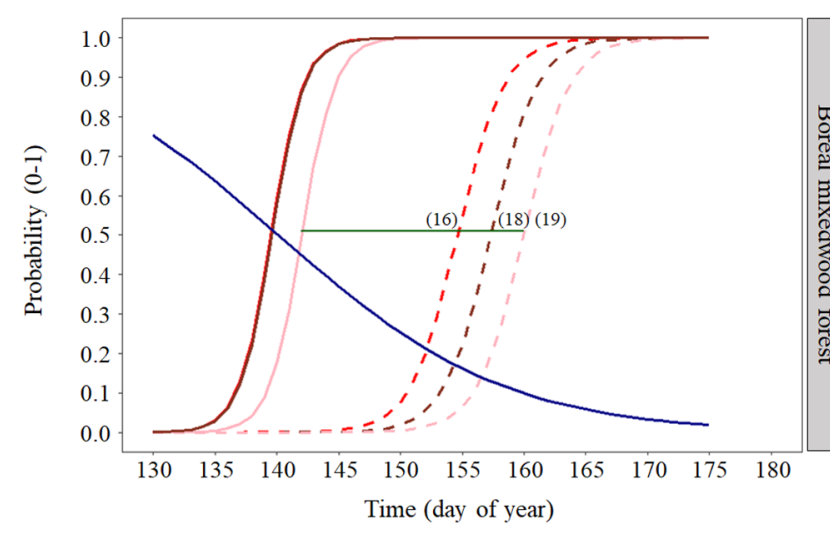

Bud phenology stage transition

- Stage transition $0 \rightarrow 2$

- -Stage transition $5 \rightarrow 6$

Climate variable

— Frost probability

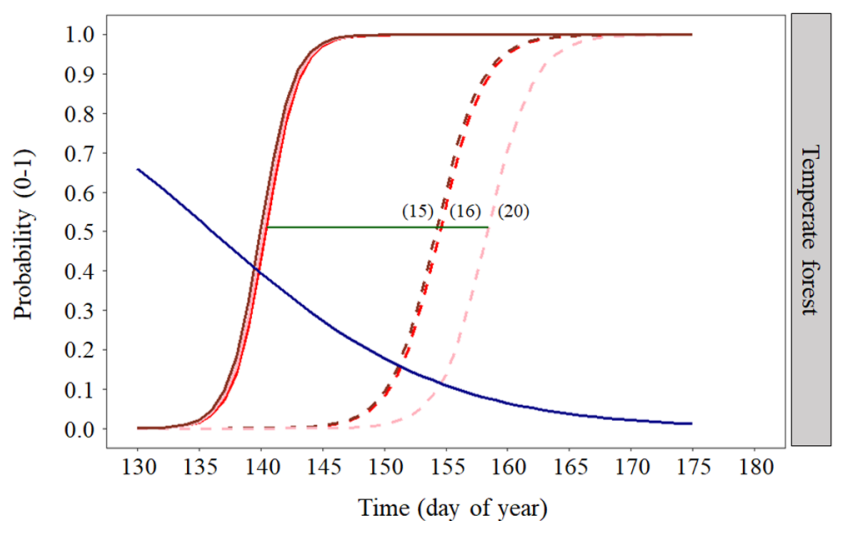

Seed sources

—Cushing (K20)

- Petawawa (K24)

- Local (J70)

FIGURE 6 | White spruce intraspecies variation in bud break timing showing the transition probabilities between the first and last transition stages of bud phenology per seed source, plantation site, and frost probability with time. The horizontal green line shows the duration of the bud break process for the local white spruce seed source naturally growing close to the boreal mixedwood forest plantation (J70) and the numbers in parenthesis show the duration (in days) of the bud break process per seed source and site.

degree-days, and opened their buds under a higher probability of spring frost occurrence than the seed source from the boreal mixedwood forest (Table 5).

Since coefficients for the photoperiod models were stronger than those of the frost probability models, seed sources from the temperate forest were more sensitive to photoperiod than the local seed source originating from the boreal mixedwood forest (Tables S20 and S21). This result is further supported since the frost probability model is incapable of predicting the observed earlier bud opening of seed sources from the temperate forest compared to the seed source from the boreal mixedwood forest whereas the photoperiod model more accurately predicts this difference in bud break timing (Table 5).

For the Norway spruce, the early emerging seed source K55 was more sensitive to the probability of spring frost occurrence for the first two transitions (Table 6 and Tables S25 to S29), was more sensitive to photoperiod for phenological stages one to five (Table 6 and Tables S25 to S29), and was more sensitive to growing degree-days for phenological stages four to six compared to later emerging seed sources K35, K39, and K50 (Table 6 and Tables S25 to S29). Therefore, the seed source K55 required shorter day lengths, fewer growing degree-days, and opened its buds under a higher probability of spring frost occurrence than late-emerging seed sources (Table 6 and Tables S25 to S29).

\section{Heating Requirements for Bud Flush Based Upon a Degree-Day Threshold}

The stage where needles are exposed to air temperate (stage five, see Table 3) is the stage that is conventionally analyzed (Hunter and Lechowicz, 1992; Hannerz, 1999; Snyder et al., 1999). Therefore, we used our mixed binomial regression model to predict the number of growing degree-days that were required for buds to reach that stage of bud phenology (stage five, see Table 3). At both plantation sites, white spruce's buds required fewer heating units to break compared to buds of black spruce and Norway spruce (Table 4). At the temperate forest site, buds of all three spruce species required fewer heating units to break compared to those at the boreal mixedwood forest site (Table 4).

At the intraspecies level, all three white spruce seed sources required on average 56 more heating units at the boreal mixedwood plantation to break compared to the temperate forest site. In both plantation sites, buds of the nonlocal southern white spruce seed sources K20 and K24 required on average 26 fewer heating units to break compared to buds of the northern seed source J70 (Table 5). All Norway spruce seed 


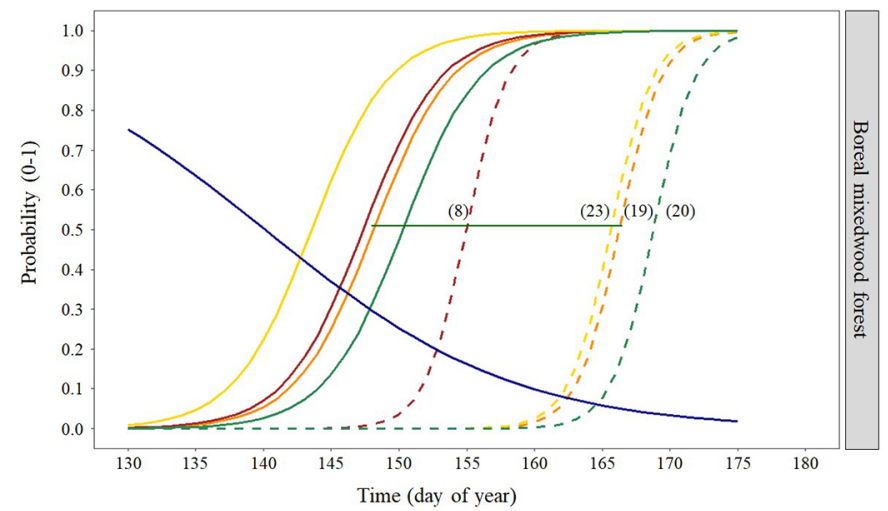

Bud phenology stage transition

- Stage transition $0->2$

- - Stage transition 5->6

Climate variable

- Frost probability

Seed sources

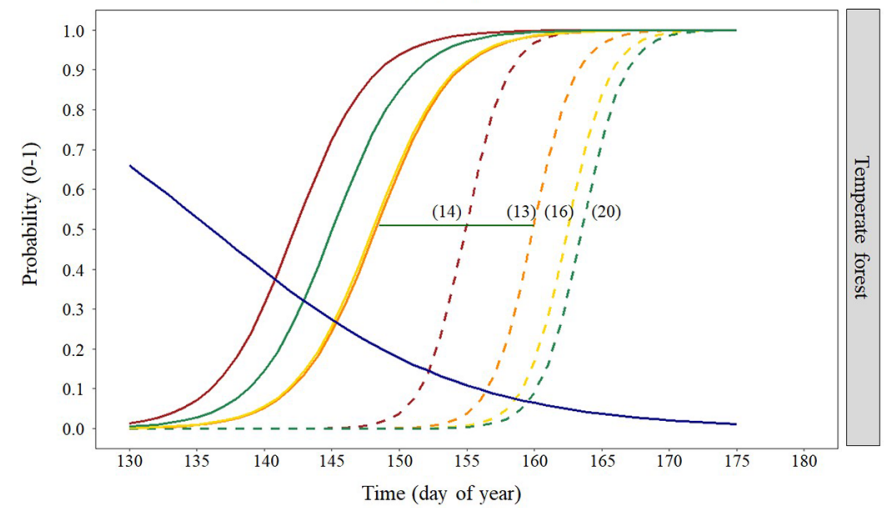

- Glubokskii (K35)

— Istebna (K39)

— Gorodokskii (K50)

- Auce (K55)

FIGURE 7 | Norway spruce intraspecies variation in bud break timing showing the transition probabilities between the first and last transition stages of bud phenology per seed source, plantation site, and frost probability with time. The horizontal green line shows the duration of the bud break process for the K50 seed source naturally growing in Gorodokskii (Belarus) and the numbers in parenthesis show the duration (in days) of the bud break process per seed source and site.

A

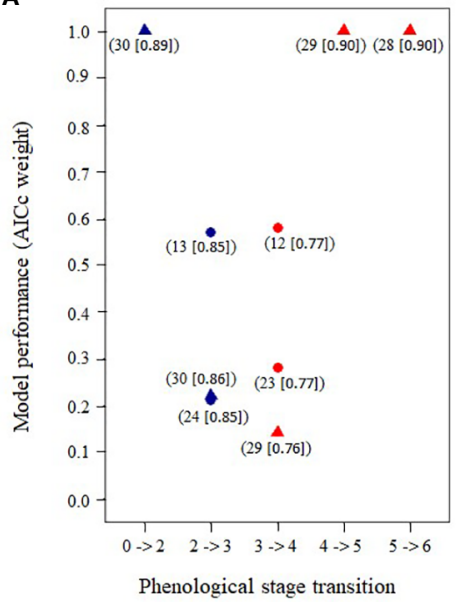

B

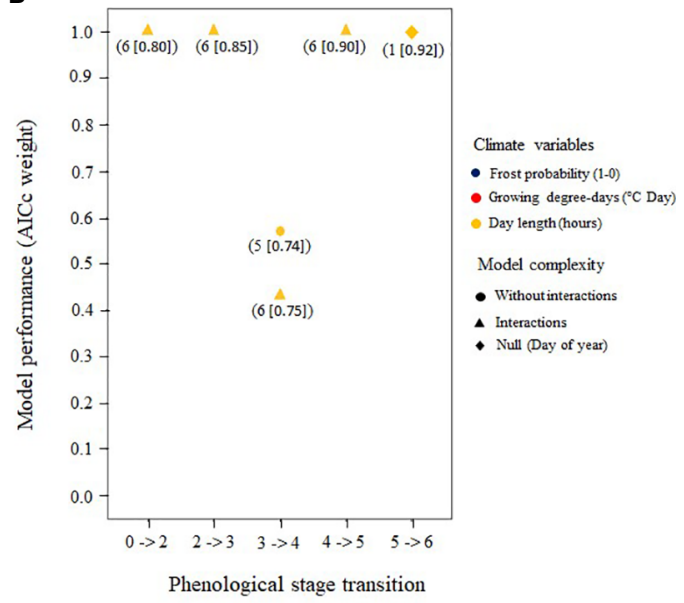

FIGURE 8 | Best air temperature models (A) and best photoperiod models (B) predicting the transition of buds from a given stage to the next based upon corrected Akaike's information criteria (AICC) weights; only models with an AlCc $>0.05$ for each of the five bud phenology transitions are shown. Numbers in parentheses under each model refer to the candidate models prior to selection (Tables S3 and $\mathbf{S 4}$ ) and the numbers in brackets show the total amount of explained variance. 


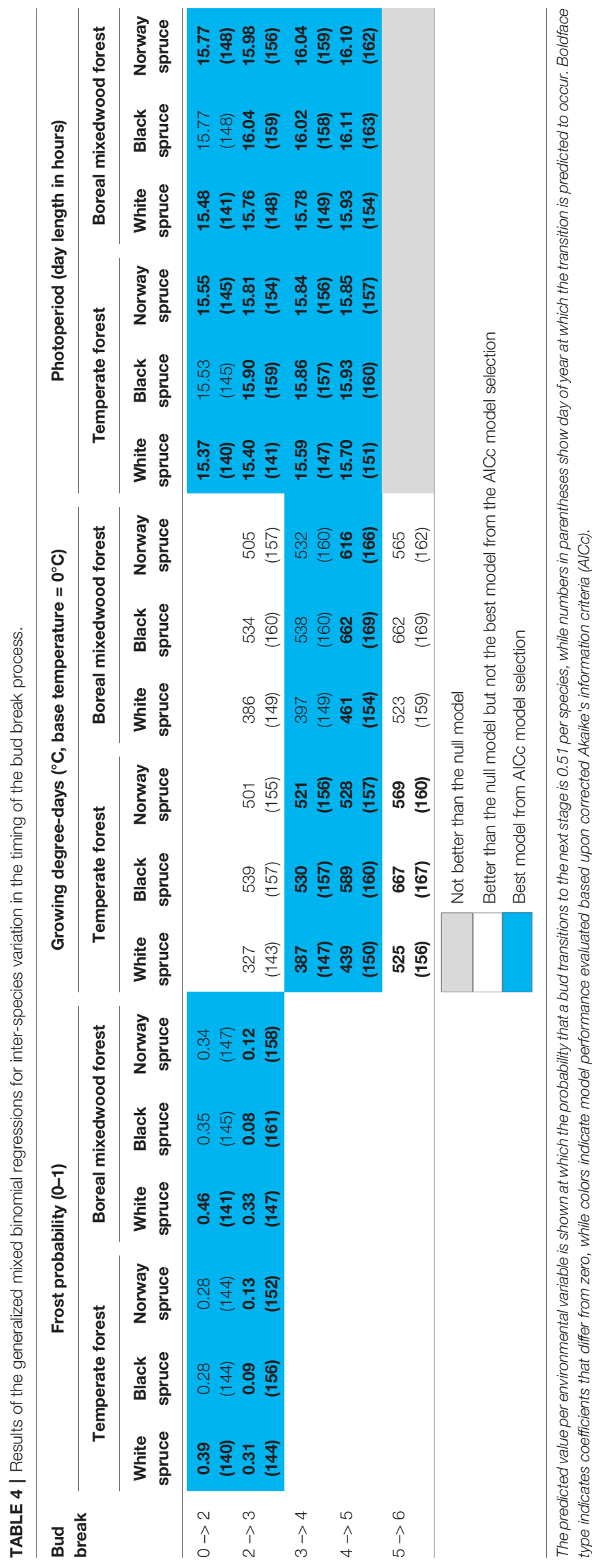

sources required more heating units in the boreal mixedwood forest than in the temperate forest to break their buds. At both sites, the Norway spruce seed source K55 required fewer heating units to break its buds compared to all remaining Norway spruce seed sources (Table 6).

\section{DISCUSSION}

\section{Inter- and Intraspecies Variation in the Timing of Bud Break}

Bud flush started first for white spruces, followed by black spruces, and lastly, by Norway spruces, while the termination of bud flush ended first in white spruces, then in Norway spruces, and finally in black spruces. O'Reilly and Parker (1982), and Numainville and Desponts (2004) reported the same species ordering for the bud flush sequences. For each species, bud flush ended earlier in the temperate forest than in the boreal mixedwood forest plantation. The time required for buds to complete their leaf-out was within the 15-23 day range recorded for white spruces (16-19 days vs. 18 days reported by Rossi and Isabel, 2017), for black spruces (19-23 days vs. 15-23 days reported by Rossi and Bousquet, 2014; Sylvestro et al., 2019), and for Norway spruces (15-17 days vs. 18-23 days reported by Fløistad and Granhus, 2010). The shorter duration of black spruce bud flush in the boreal mixedwood relative to the temperate forest may result from an adaptation selected to maximize carbon gains during the shorter growing season of the north (Clark et al., 2014b; Sylvestro et al., 2019). Yet, the duration of bud flush of white spruce and Norway spruce was not faster in the boreal mixedwood forest compared to the temperate forest. Given that our study sites covered a small portion $\left(47^{\circ}-\right.$ $48^{\circ} \mathrm{N}$ ) of continent-wide species ranges likely contributed to the observed decrease in clinal trend in bud flush with latitude. Still, earlier bud flush of nonlocal white spruce seed sources, when compared to the local white spruce seed source in the boreal mixedwood plantation, increased their probability of exposure to spring frosts, a result that was also reported in a transplant study conducted on 23 white spruce seed sources in Ontario (Canada) by Lu and Man (2011).

At both sites, three Norway spruce seed sources followed a similar bud break sequence (K35, K39 and K50) whereas the K55 seed source from Latvia completed its bud break $\sim 10$ days earlier. Since the Norway spruce is widely distributed in Europe, different tree populations are probably adapted to their local conditions (Matras, 2009; Chmura et al., 2018), thus, the earlier bud break from the Latvia seed source probably reflects a local adaptation. The similar bud break sequence from three different Norway spruce seed sources could suggest weak local adaptations regarding the bud break sequence or that the eastern Canadian boreal forest is so stressful to these three Norway spruce seed sources that it masked their difference in bud break sequence. Effectively, Klisz et al. (2019) showed that when climate is the most important factor determining the development of trees such as at the margin of a species range, the importance of local adaptation is reduced. 
TABLE 5 | Results of generalized mixed binomial regressions for white spruce intraspecies variation in the timing of the bud break process.

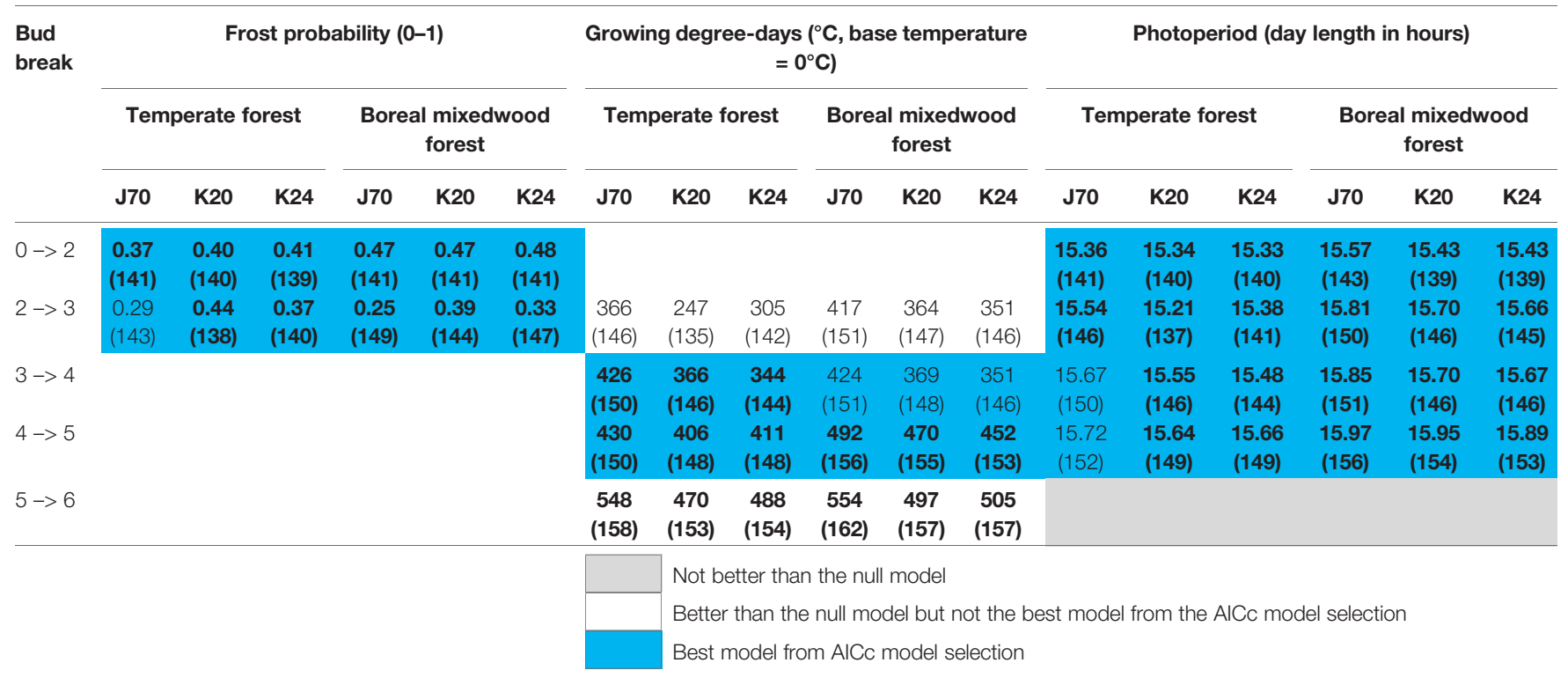

The predicted value per environmental variable is shown at which the probability that a bud transitions to the next stage is 0.51 per seed source, while numbers in parentheses show day-

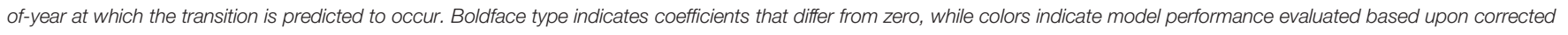
Akaike's information criteria (AICC).

\section{Interspecies Variation in the Effect of Air Temperature and Photoperiod for Predicting Bud Break Phenology}

White spruces exhibited a clear change in sensitivity to air temperature variables, consistent with our hypothesis. Its first stages were driven by spring frost occurrence, whereas its intermediate and final stages were driven by growing degreedays. Therefore, the white spruce shifts its strategy from frost avoidance in the early stages to maximize the growing season length by flushing buds more rapidly with increasing air temperature for the intermediate and final stages. Specifically, spring frost occurrence was most important in controlling bud flush in the boreal forest, where this phenomenon was the most frequent. In contrast, sensitivity to photoperiod in the temperate forest could replace the lower spring frosts occurrence to trigger bud flush. In environments where spring frosts rarely damage trees severely, day length would be the environmental variable driving bud break timing. Both the black spruce and the Norway spruce, however, were less sensitive to spring frosts occurrence, but they were sensitive to growing degree-days for their intermediate and final stages of bud phenology. The black spruce was the least sensitive species to both growing degree-days and spring frost occurrence, but its late bud flush prevented damage to buds from spring frost events and its faster completion of the bud break process could maximize growing season length. Thus, late-emerging species may wait for a low frost frequency before opening their buds, but hasten their development, which maximizes the growing season length. In contrast, earlyemerging species may develop their buds earlier, but more slowly to keep the leaf primordia protected by the bud scales while frost probability is high.
Since our study is only empirical, future experiments also aiming to disentangle the importance of frost, photoperiod and growing degree-days on the bud break sequence of spruces should be conducted and compared to our results. Still, frost probability in late spring represents a just simplification of the evolutionary tradeoff imposed on boreal and temperate trees by the freezing temperatures. Even if laboratory studies suggest that frost events of low intensity have minimal impact on the bud break sequence of spruces since the dehardening threshold values preventing frost damage to buds decreased from $-10^{\circ} \mathrm{C}$ at the swelling stage to $-5^{\circ} \mathrm{C}$ at the bud break stage (Glerum, 1973; Repo, 1992; Bigras and Hébert, 1996), it contradicts with the frost damage to buds or newly formed foliage we observed (gray-black buds or brown-white needles leaning downward, Figure S3) after a night frost of $-2^{\circ} \mathrm{C}$ (data not shown), which was also reported by Cannell (1984). Frost damage to buds probably follows a dynamic process where frost damage occurs when the heat loss by trees at night exceeds the heat accumulated during the day. Since laboratory studies likely grew seedlings to air temperatures above those observed in the field, field trees probably accumulated less heat during the day and could therefore be damaged by less intense frost events. Since the synchrony between spring frosts and the bud break was shown to be an important aspect of tree fitness (Vitra et al., 2017), the probability of spring frost could better represent the evolutionary pressure imposed by late-spring frosts on the survival of trees compared to growing degree-days.

\section{Intraspecies Variation in the Effect of Air Temperature and Photoperiod for Predicting Bud Break Phenology}

We tried to quantify the capacity of nonlocal white and Norway spruce seed sources to adapt when transplanted to a new climate 


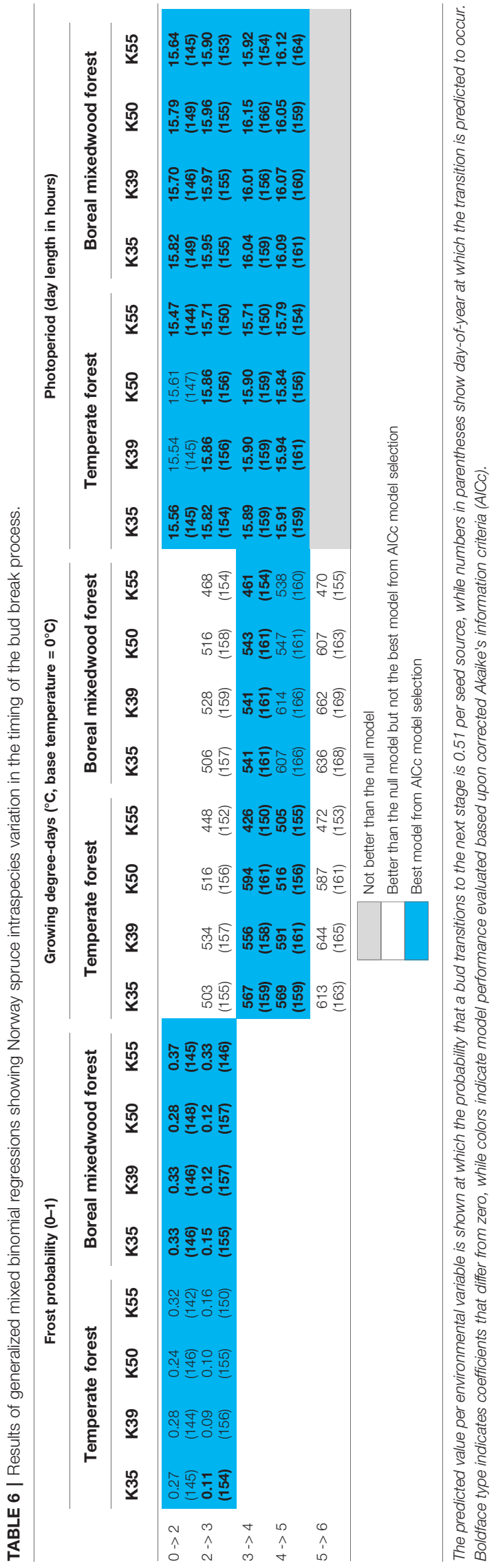

that was used as a proxy for climate change. We showed that nonlocal white spruce seed sources originating from the southern temperate forest opened their buds earlier than did the local seed source from the boreal mixedwood forest. Therefore, nonlocal southern seed sources could only partly adapt to their new climate, which is consistent with our hypothesis. Specifically, early stages of bud phenology of the nonlocal (southern) white spruce seed sources were more sensitive to photoperiod compared to the local seed source and were also more sensitive to growing degree-days for their intermediate stages of bud phenology. Our results for the black spruce seed source originating from the boreal forest, where spring frost probability is high, showed that bud flush was slightly more sensitive to air temperature than to photoperiod. We propose a general explanation driving the leaf-out process in spring. On one hand, tree populations that are growing in environments where spring frost is frequent and likely throughout the growing season, as is the case in the boreal forest, have adapted to the risk of frost damage. Accordingly, onset of bud flush is driven by frost probability. On the other hand, tree populations that are growing in environments where air temperature warms more rapidly, and where spring frost probability decreases quickly, have adapted to a photoperiod-triggered leaf-out, concomitant with the decrease in spring frost probability.

As in previous studies, we found a large within-tree variation in bud break timing (Rousi and Heinonen, 2007; Sylvestro et al., 2019) that probably results from an adaptation to limit the damage caused by spring frosts. The late bursting of some buds ensures that trees can still grow even if some buds were damaged by spring frosts. However, this large variation in bud break timing caused some problems when we predicted the average date buds transit from a phenological stage to the next because the predicted date at which buds reached late transitions could have been predicted prior to the dates at which buds reached earlier transitions (Figure 4). By analyzing each step separately instead of analyzing each step in a single model, we might have increased the overlap between stages (Clark et al., 2014a; Clark et al., 2014b). The overlap problem was mostly observed for Norway spruce seed sources (K50 and K55). Since the predictions were based upon the probability $(0.51)$ that buds transited toward the next stage, the probability that buds did not transit was still of 0.49 , which might have increased the overlap problem between successive stages. Had we chosen a different threshold value; the proportion of overlap would have also changed. We confirm that at the bud level no late stages were registered before earlier ones therefore, the overlap problem is likely due to the large variation in bud break timing between trees and to the smaller sample size at the seed source level. Still, errors were of fewer days than our sampling interval. Given the logistical constraints, it was not possible to sample at a shorter time interval. Since it is common for bud phenology data to show some overlap between successive stages (Clark et al., 2014a), these rare problems unlikely discredit the general conclusion of our study but call for increasing studies analyzing each stage of the bud break process, which for now are still scarce. We acknowledge that Clark et al. (2014a; 2014b) developed a continuous 
development model (CDM) consisting of a Multinomial Hidden Markov Chain within a Bayesian framework to analyze the bud break process, but the greater complexity of running this model compared to running separated binomial regressions informed our choice.

\section{Heating Requirements for Bud Flush Based on Growing Degree-Day Thresholds}

The bursting of buds is a phenotypic trait that is under the control of both genetic and phenotypic plasticity (Worrall and Mergen, 2006; Yakovlev et al., 2006; Pelgas et al., 2011; Rossi and Bousquet, 2014). However, the share of both components (genetics and phenotypic plasticity) is likely species- and population-dependent, thus, the capacity of different tree populations to vary their timing of bud break according to changes in climate will vary across tree populations and species. With heating requirement for bud flush varying between 77 and 1278 growing degree-days, the Norway spruce is a spruce species showing high variations in timing of bud break compared to the white spruce, which required between 233 and 360 degree-days (Man and Lu, 2010; Man et al., 2016; Man et al., 2017) and the black spruce, which required between 284 and 514 growing degree-days (Bronson et al., 2009; Antonucci et al., 2015; Man et al., 2016). In our study, the number of GDDs that were required for white (450 GDD) and black spruce, (626 GDD) bud flush was slightly above their previously reported upper range whereas the Norway spruce (572 GDD) was in the middle of its reported range.

Blum (1988) developed the hypothesis that populations of trees growing in colder sites (north) would require fewer heating units to flush their buds compared to southern populations. Similar results were reported by Sylvestro et al. (2019). In the present study, the heating requirement for all three spruce species were higher at the boreal mixedwood plantation site and contrast with Blum's (1988) hypothesis. However, our results are consistent with our hypothesis that frost probability outperformed degree-day sums to trigger onset of bud flush. We suggest that in sites where spring frost probability is high, onset of bud flush is postponed, which also increases their heating requirement whereas in sites where spring frost frequency is low, buds flush sooner, which decreases their heating requirement. Yet, complexity arises because air temperature increases more slowly in the boreal site. Even if bud flush is later in terms of calendar days, accumulated degreedays can still be lower compared to temperate sites where air temperature increases more rapidly. We suggest that the intraspecies variation in heating requirement found in previous studies probably represents the variation in spring frost probability that is experienced by the different tree populations. Even if traditional studies have used growing degree-days to predict bud flush, we have advanced the idea that spring frost occurrence is the main driver of spruce bud flush. In fact, Kollas et al. (2014) showed that the environmental driver common to both altitudinal and latitudinal species range limitation was frost risk during leaf-out. Frost probability was also shown to drive the leaf-out process of various tree species along an altitudinal gradient in Switzerland (Lenz et al., 2016) and on the Tibetan Plateau (Wang et al., 2019). Therefore, ecophysiological models of bud break should include spring frost variables.

\section{Adaptation Capacity to Spring Frosts in the Context of Climate Change}

Spring frosts are daily events that require a set of specific meteorological conditions, such as a night without wind and clouds, to occur (Laughlin and Kalma, 1987; Lindkvist and Lindqvist, 1997; Chung et al., 2006). These specific conditions are hardly modeled with accuracy by climate change models. Since climate change already increased the global mean annual temperature by $1^{\circ} \mathrm{C}$ (Allen et al., 2018) but that spring frosts still occur frequently in boreal mixedwood forests (see Study site section), climate warming over the next 50 years will unlikely decrease the future frequency and intensity of spring frosts enough to limit their impact on tree growth. Consistent with previous studies assessing the impact of climate change on bud phenology (Polgar et al., 2013; Olsson et al., 2017), our results suggest that bud flush of spruce species would hasten in the future because higher air temperatures will accelerate transitions of the temperature-sensitive stages of bud phenology. Yet, photoperiod-sensitive stages of bud phenology should limit premature leaf-out and become a more prominent safety mechanism preventing frost damage. Experimental temperature manipulations have shown that the bud break sequence of boreal tree species was completed earlier when they were artificially heated, but that faster bud break was restricted to the last stages of bud phenology, which are the stages we demonstrated to be less sensitive to photoperiod (Rossi, 2015; Rossi and Isabel, 2016; Rossi and Isabel, 2017). It was also shown that the first stages of bud phenology were under stronger genetic control compared to the last phenological stages (Perrin et al., 2017). Under a warmer climate, we would expect earlier bud flush in spruce species that are growing in boreal mixedwood forests, since they are more sensitive to air temperature compared to spruce species growing in southern temperate forests. We also expected that the black spruce, which is less photoperiod-sensitive than the white spruce, would advance its bud phenology more rapidly, which would increase its risk of frost damage. Overall, convergence of bud phenology across spruce species is to be expected, an observation that has also been reported over altitudinal gradients (Chen et al., 2018; Vitasse et al., 2018).

Our results can also guide climate-smart forestry practices aiming to manage the boreal-temperate forest ecotone in a sustainable way (Nagel et al., 2017; Verkerk et al., 2020). The long (60-100 years) rotation length of spruce plantations established in the boreal mixedwood forest paired with the fast rate of climate warming ensures that trees currently planted will be growing in a warmer climate than the current climate. However, planting for the future first requires the survival of the planted seedlings in their early years. Accordingly, photoperiod-sensitive seed sources such as the southern with spruce seed sources consist in a poor choice for establishing productive plantations in the boreal mixedwood forest since these seed sources will likely be frequently damaged by spring 
frosts. Local seed sources better adapted to prevent damage from spring frost consist in a better choice for establishing productive plantations. Since the black spruce is the spruce species that burst its buds the latest, it is the least likely species to be damaged by spring frosts, therefore, it currently represents the best species to plant in spring frost-prone environments. However, the warming of air temperature paired with the black spruce low photoperiod sensitivity should hasten its future bud burst and increase its exposure to spring frost, thus, probably reducing its future productivity. Interestingly, we showed that assisted migration and the use of foreign species might not always be a good option for increasing tree productivity, mostly when extreme events such as spring frosts can importantly damage trees.

\section{CONCLUSION}

Our novel approach allowed us to identify the probability of spring frost occurrence as the driver of bud break onset, while growing degree-days drove the intermediate and final phenological stages of bud break. Incorporating this change in sensitivity to climate along the bud break sequence should increase the realism of process-based models of bud burst in temperate and boreal tree species. Further, its inclusion should increase the accuracy of predicting the response of bud break phenology to climate change and help to plan forest management practices that could mitigate the negative effects of climate change on forest productivity.

\section{DATA AVAILABILITY STATEMENT}

The raw data supporting the conclusions of this article are stored as a research dataset on the Mendeley reference management software http://dx.doi.org/10.17632/2t4b33ftst.1.

\section{REFERENCES}

Allen, M. R., Dube, O. P., Solecki, W., Aragón-Durand, F., Cramer, W., Humphreys, $\mathrm{S}$., et al (2018). Framing and Context. In: Global Warming of $1.5^{\circ} \mathrm{C}$. An IPCC Special Report on the impacts of global warming of $1.5^{\circ} \mathrm{C}$ above pre-industrial levels and related global greenhouse gas emission pathways, in the context of strengthening the global response to the threat of climate change, sustainable development, and efforts to eradicate poverty. Masson-Delmotte, V. P., Zhai, H. -O., Pörtner, D., Roberts, J., Skea, P. R., Shukla, A., et al. (eds.) In Press.

Antonucci, S., Rossi, S., Deslauriers, A., Lombardi, F., Marchetti, M., and Tognetti, R. (2015). Synchronisms and correlations of spring phenology between apical and lateral meristems in two boreal conifers. Tree Physiol. 35, 1086-1094. doi: 10.1093/treephys/tpv077

Aono, Y., and Kazui, K. (2008). Phenological data series of cherry tree flowering in Kyoto, Japan, and its application to reconstruction of springtime temperatures since the $9^{\text {th }}$ century. Int. J. Climatol. 28, 905-914. doi: 10.1002/joc.1594

Augspurger, C. K. (2009). Spring 2007 warmth and frost: phenology, damage and refoliation in a temperate deciduous forest. Funct. Ecol. 23, 1031-1039. doi: 10.1111/j.1365-2435.2009.01587.x

Barton, K. (2018). MuMIn: Multi-Model Inference. R package version 1.42.1.

Basler, D., and Körner, C. (2012). Photoperiod sensitivity of bud burst in 14 temperate forest tree species. Agric. For. Meteorol. 165, 73-81. doi: 10.1016/ j.agrformet.2012.06.001

\section{AUTHOR CONTRIBUTIONS}

The experimental plantations were designed and established in 2002 by FT. BM developed the hypotheses to be tested, determined the sampling procedures, did the field work, analyzed the data, and wrote the first draft of the manuscript. YB and MS helped to develop the hypotheses, the methods, the statistical analyses, and all authors contributed substantially to writing the final manuscript.

\section{FUNDING}

This research project was funded through a grant provided by the Natural Science and Engineering Research Council of Canada (NSERC) to FT and colleagues.

\section{ACKNOWLEDGMENTS}

We thank the Natural Sciences and Engineering Research Council of Canada (NSERC) for funding this research project. We acknowledge the valuable field assistance provided by $\mathrm{L}$. Gervais and R. Mincheva. We are also grateful to F. Rousseau, who provided support and advice on the statistical analysis, together with the $\mathrm{R}$ codes that were used in this research project, and to P. Duval for his help in identifying the stages of bud phenology.

\section{SUPPLEMENTARY MATERIAL}

The Supplementary Material for this article can be found online at: https://www.frontiersin.org/articles/10.3389/fpls.2020.01031/ full\#supplementary-material

Basler, D. (2016). Evaluating phenological models for the prediction of leaf-out dates in six temperate tree species across central Europe. Agric. For. Meteorol. 217, 10-21. doi: 10.1016/j.agrformet.2015.11.007

Bates, D., Maechler, M., Bolker, B., and Walker, S. (2015). Fitting linear mixedeffects models using lme4. JSS 67, 1-48. doi: 10.18637/jss.v067.i01

Bigras, J. F., and Hébert, C. (1996). Freezing temperatures and exposure times during bud break and shoot elongation influence survival and growth of containerized black spruce (Picea mariana) seedlings. Can. J. For. Res. 26, 1481-1489. doi: 10.1139/x26-165

Blouin, D., Beaulieu, J., Daoust, G., and Poliquin, J. (1994). Wood quality of Norway spruce grown in plantations in Québec. Wood Fiber Sci. 26, 342-353.

Blum, B. M. (1988). Variation in the phenology of bud flushing in white and red spruce. Can. J. For. Res. 18, 315-319. doi: 10.1139/x88-048

Bronson, D. R., Gower, S. T., Tanner, M., and Van Herk, I. (2009). Effect of ecosystem warming on boreal black spruce bud burst and shoot growth. Glob. Change Biol. 15, 1534-1543. doi: 10.1111/j.1365-2486.2009.01845x

Brown, A. (2019). Seasonally uneven warming. Nat. Climate Change 9, 186. doi: 10.1038/s41558-019-0431-y

Caffarra, A., and Donnelly, A. (2011). The ecological significance of phenology in four different tree species: effects of light and temperature on bud burst. Int. J. Biometeorol. 55, 711-721. doi: 10.1007/s00484-010-0386-1

Cannell, M. G. R., and Smith, R. I. (1986). Climatic warming, spring budburst and forest damage on trees. J. Appl. Ecol. 23, 177-191. doi: 10.2307/2403090 
Cannell, M. G. R. (1984). Spring frost damage on young Picea sitchensis. I. Occurrence of damaging frosts in Scotland compared with western North America. Forestry 57, 159-175. doi: 10.1093/forestry/57.2.159

Chen, L., Huang, J. G., Ma, Q., Hänninen, H., Rossi, S., Piao, S., et al. (2018). Spring phenology at different altitudes is becoming more uniform under global warming in Europe. Glob. Change Biol. 24, 3969-3975. doi: 10.1111/gcb.14288

Chmura, D. J., Matras, J., Barzdajn, W., Buraczyk, W., Kowalkowski, W., Kowalczyk, J., et al. (2018). Variation in growth of Norway spruce in the IUFRO 1972 provenance experimental series. Silvae Genet. 67, 26-33. doi: $10.2478 /$ sg-2018-0004

Chuine, I. (2000). A unified model for budburst of trees. J. Theor. Biol. 207, 337347. doi: $10.1006 /$ jtbi.2000.2178

Chung, U., Seo, H. H., Hwang, K. H., Hwang, B. S., Choi, J., Lee, J. T., et al. (2006). Minimum temperature mapping over complex terrain by estimating cold air accumulation potential. Agric. For. Meteorol. 137, 15-24. doi: 10.1016/ j.agrformet.2005.12.011

Clark, J. S., Melillo, J., Mohan, J., and Salk, C. (2014a). The seasonal timing of warming that controls onset of the growing season. Glob. Change Biol. 20, 1136-1145. doi: $10.1111 /$ gcb.12420

Clark, J. S., Salk, C., Melillo, J., and Mohan, J. (2014b). Tree phenology responses to winter chilling, spring warming, at north and south range limits. Funct. Ecol. 28, 1344-1355. doi: 10.1111/1365-2435.12309

Clements, J. R., Fraser, J. W., and Yeatman, C. W. (1972). Frost damage to white spruce buds. Can. J. For. Res. 2, 62-63. doi: 10.1139/x72-013

Cooke, J. E. K., Eriksson, M. E., and Junttila, O. (2012). The dynamic nature of bud dormancy in trees: environmental control and molecular mechanisms. Plant Cell Environ. 35, 1707-1728. doi: 10.1111/j.1365-3040.2012.02552.x

D'Orangeville, L., Houle, D., Duchesne, L., Phillips, R. P., Bergeron, Y., and Kneeshaw, D. (2018). Beneficial effects of climate warming on boreal tree growth may be transitory. Nat. Commun. 9, 3213. doi: 10.1038/s41467-018-05705-4

Dhont, C., Sylvestre, P., Gros-Louis, M. C., and Isabel, N. (2010). Field Guide for identifying apical bud break and bud formation stages in white spruce. Ressources naturelles Canada, Service canadien des forêts, Centre de foresterie des Laurentides. ISBN: 978-1-100-93942-1.

Du, J., Li, K., He, Z., Chen, L., Zhu, X., and Lin, P. (2019). Age-mediation of treegrowth responses to experimental warming in the northeastern Tibetan Plateau. Ecol. Evol. 9, 2242-2254. doi: 10.1002/ece3.4920

Dugas, C. (1975). Le climat et son influence sur l'agriculture abitibienne. Sud de la baie de James et partie de l'enclave argileuse de l'Objibway. Collection Nordicana (Volume 39), Centre d'etudes nordiques, Université Laval, Québec, Canada. pp.140. doi: 10.5885/464018ND-DEA2492A1.

Dy, G., and Payette, S. (2007). Frost hollows of the boreal forest as extreme environments for black spruce tree growth. Can. J. For. Res. 37, 492-504. doi: 10.1139/X06-235

Easterling, D. R., Meehl, G. A., Parmesan, C., Changnon, S. A., Karl, T. R., and Mearns, L. O. (2000). Climate Extremes: Observations, Modeling, and Impacts. Science 289, 2068-2074. doi: 10.1126/science.289.5487.2068

Environment Canada (2019a). Barrage Angliers weather station, normal 19812010. http://climate.weather.gc.ca/climate_normals/results_1981_2010_f. $\mathrm{html}$ ? search Type $=\operatorname{stn}$ Prov $\& 1$ st Province $=\mathrm{QC} \& \operatorname{txtCentralLatMin}=$ 0\&txtCentralLatSec $=0$ \&txtCentralLongMin $=0$ \&txtCentralLongSec $=0 \&$ stnID $=$ 5976\&dispBack $=0$. [accessed accessed 1 April 2018].

Environment Canada (2019b). Mont-Brun weather station, normal 1981-2010. http://climate.weather.gc.ca/climate_normals/results_1981_2010_f.html?

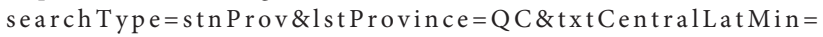
$0 \&$ txtCentralLatSec $=0 \&$ txtCentralLongMin $=0 \&$ txtCentralLongSec $=0 \&$ stnID $=$ 5988\&dispBack $=0$. [accessed 1 April 2018].

Environment Canada (2019c). Sunset calculator. https://www.nrccnrc.gc.ca/eng/ services/sunrise/advanced.html. [accessed 1 April 2018].

Estiarte, M., and Peñuelas, J. (2015). Alteration of the phenology of leaf senescence and fall in winter on deciduous species by climate change: effects on nutrient proficiency. Glob. Change Biol. 21, 1005-1017. doi: 10.1111/gcb.12804

Fløistad, S. I., and Granhus, A. (2010). Bud break and spring frost hardiness in Picea abies seedlings in response to photoperiod and temperature treatments. Can. J. For. Res. 40, 968-976. doi: 10.1139/X10-050

Fu, Y. H., Piao, S., Delpierre, N., Hao, F., Hänninen, H., Liu, Y., et al. (2017). Larger temperature response of autumn leaf senescence than spring leaf-out phenology. Glob. Change Biol. 24, 2159-2168. doi: 10.1111/gcb.14021
Fuchigami, L. H., and Nee, C. C. (1987). Degree growth stage model and restbreaking mechanisms in temperate woody perennials. Hortic. Sci. 22, 836-845.

Glerum, C. (1973). Annual trends in frost hardiness and electrical impedance for seven coniferous species. Can. J. Plant Sci. 53, 881-889. doi: 10.4141/cjps73-170

Hänninen, H. (2006). Climate warming and the risk of frost damage to boreal forest trees: identification of critical ecophysiological traits. Tree Physiol. 26, 889-898. doi: 10.1093/treephys/26.7.889

Hänninen, H. (2016). Boreal and temperature trees in a changing climate, modelling the ecophysiology of seasonality (Helsinki, Finland: Springer).

Hannerz, M. (1999). Evaluation of temperature models for predicting bud burst in Norway spruce. Can. J. For. Res. 29, 9-19. doi: 10.1139/x98-175

Hufkens, K., Friedl, M. A., Keenan, T. F., Sonnentag, O., Bailey, A., O'Keefe, J., et al. (2012). Ecological impacts of a widespread frost event following early spring leaf-out. Glob. Change Biol. 18, 2365-2377. doi: 10.1111/j.13652486.2012.02712.x

Hunter, A. F., and Lechowicz, M. J. (1992). Predicting the timing of budburst in temperate trees. J. Appl. Ecol. 29, 597-604. doi: 10.2307/2404467

Inouye, D. W. (2008). Effects of climate change on phenology, frost damage, and floral abundance of montane wildflowers. Ecology 89, 353-362. doi: 10.1890/ 06-2128.1

Jeong, S. J., Ho, C. H., Gim, H. J., and Brown, M. E. (2011). Phenology shifts at start vs. end of growing season in temperature vegetation over the Northern Hemisphere for the period 1982-2008. Glob. Change Biol. 17, 2385-2399. doi: $10.1111 / j .1365-2486.2011 .02397 . x$

Körner, C., Basler, D., Hoch, G., Kollas, C., Lenz, A., Randin, C. F., et al. (2016). Where, why and how? Explaining the low-temperature range limits of temperate tree species. J. Ecol. 104, 1076-1088. doi: 10.1111/1365-2745.12574

Klisz, M., Buras, A., Sass-Klaassen, U., Puchałka, R., Koprowski, M., and Ukalska, J. (2019). Limitations at the Limit? Diminishing of Genetic Effects in Norway Spruce Provenance Trials. Front. Plant Sci. 10, 306. doi: 10.3389/ fpls.2019.00306

Kollas, C., Körner, C., and Randin, C. F. (2014). Spring frost and growing season length co-control the cold range limits of broad-leaved trees. J. Biogeogr. 41, 773-783. doi: 10.1111/jbi.12238

Lang, W., Chen, X., Qian, S., Liu, G., and Piao, S. (2019). A new process-based model for predicting autumn phenology: How is leaf senescence controlled by photoperiod and temperature coupling? Agric. For. Meteorol. 268, 124-135. doi: 10.1016/j.agrformet.2019.01.006

Laughlin, G. P., and Kalma, J. D. (1987). Frost hazard assessment from local weather and terrain data. Agric. For. Meteorol. 40, 1-16. doi: 10.1016/01681923(87)90050-5

Lenz, A., Hoch, G., Körner, C., and Vitasse, Y. (2016). Convergence of leaf-out towards minimum risk of freezing damage in temperate trees. Funct. Ecol. 30, 1480-1490. doi: 10.1111/1365-2435.12623

Lindkvist, L., and Lindqvist, Q. (1997). Spatial and temporal variability of nocturnal summer frost in elevated complex terrain. Agric. For. Meteorol. 87, 139-153. doi: 10.1016/S0168-1923(97)00021X

Linkosalo, T., Häkkinen, R., and Hänninen, H. (2006). Models of the spring phenology of boreal and temperate trees: is there something missing? Tree Physiol. 26, 1165-1172. doi: 10.1093/treephy/26.9.1165

Liu, Q., Fu, Y. H., Zhu, Z., Liu, Y., Liu, Z., Huang, M., et al. (2016). Delayed autumn phenology in the Northern Hemisphere is related to change in both climate and spring phenology. Glob. Change Biol. 22, 3702-3711. doi: 10.1111/gcb.13311

Liu, Q., Piao, S., Janssens, I. A., Fu, Y., Peng, S., Lian, X., et al. (2018). Extension of the growing season increases vegetation exposure to frost. Nat. Commun. 9, 426. doi: 10.1038/s41467-017-02690-y

Loarie, S. R., Duffy, P. B., Hamilton, H., Asner, G. P., Field, C. B., and Ackerly, D. D. (2009). The velocity of climate change. Nature 462, 1052-1055. doi: 10.1038/ nature08649

Lu, P., and Man, R. (2011). Assessment of assisted migration effects on spring bud flush in white spruce (Picea glauca [Moench] Voss) seedlings. For. Chron. 87, 391-397. doi: 10.5558/tfc2011-029

Ma, Q., Huang, J. G., Hänninen, H., and Berninger, F. (2018). Divergent trends in the risk of spring frost damage to trees in Europe with recent warming. Glob. Change Biol. 25, 351-360. doi: 10.1111/gcb.14479

Man, R., and Lu, P. (2010). Effects of thermal model and base temperature on estimates of thermal time to bud break in white spruce seedlings. Can. J. For. Res. 40, 1815-1820. doi: 10.1139/X10-129 
Man, R., Colombo, S., Lu, P., and Dang, Q. L. (2016). Effects of winter warming on cold hardiness and spring budbreak of four boreal conifers. Botany 94, 117126. doi: 10.1139/cjb-2015-0181

Man, R., Lu, P., and Dang, Q. L. (2017). Insufficient chilling effects vary among boreal tree species and chilling duration. Front. Plant Sci. 8, 1354. doi: 10.3389/ fpls.2017.01354

Marchand, W., Girardin, M. P., Hartmann, H., Gauthier, S., and Bergeron, Y. (2019). Taxonomy, together with ontogeny and growing conditions, drives needleleaf species' sensitivity to climate in boreal North America. Glob. Change Biol. 25, 2793-2809. doi: 10.1111/gcb.14665

Matras, J. (2002). Growth and development of polish provenances of Norway spruce (Picea abies Karst.) in the IUFRO 1972 experiment. For. Res. Papers 947, 73-97.

Matras, J. (2009). Growth and development of Polish provenances of Picea abies in the IUFRO 1972 experiment. Dendrobiology 61, 145-158.

Mazerolle, M. J. (2017). AICcmodavg: Model selection and multimodel inference based on (Q)AIC(c). R package version 2.1-1. https://cran.r-project.org/ package $=$ AICcmodavg.

Nagel, L. M., Palik, B. J., Battaglia, M. A., D'Amato, A. W., Guldin, J. M., Swanston, C. W., et al. (2017). Adaptive silviculture for climate change: A national experiment in manager-scientist partnerships to apply an adaptation framework. J. For. 115, 167-178. doi: 10.5849/jof.16-039

Numainville, G., and Desponts, M. (2004). Les stades de débourrement des bourgeons foliaires de l'épinette noire. Guide $n^{\circ}$ 7. Québec: Gouvernement du Québec, Ministère des Ressources naturelles, de la Faune et des Parcs.

O'Reilly, C., and Parker, W. H. (1982). Vegetative phenology in a clonal seed orchard of Picea glauca and Picea mariana in northwestern Ontario. Can. J. For. Res. 12, 408-4013. doi: 10.1139/x82-058

Olsson, C., Olin, S., Lindström, J., and Jönsson, A. M. (2017). Trends and uncertainties in budburst projections of Norway spruce in Northern Europe. Ecol. Evol. 7, 9954-9969. doi: 10.1002/ece3.3476

Parmesan, C., and Yohe, G. (2003). A globally coherent fingerprint of climate change impacts across natural systems. Nature 421, 37-42. doi: 10.1038/ nature 01286

Partanen, J., Koski, V., and Hänninen, H. (1998). Effects of photoperiod and temperature on the timing of bud burst in Norway spruce (Picea abies). Tree Physiol. 18, 811-816. doi: 10.1093/treephys/18.12.811

Pelgas, B., Bousquet, J., Meirmans, P. G., Ritland, K., and Isabel, N. (2011). QTL mapping in white spruce: gene maps and genomic regions underlying adaptive traits across pedigrees, years and environments. BMC Genomics 12, 145. doi: 10.1186/1471-2164-12-145

Perrin, M., Rossi, S., and Isabel, N. (2017). Synchronisms between bud and cambium phenology in black spruce: early-flushing provenances exhibit early xylem formation. Tree Physiol. 37, 593-603. doi: 10.1093/treephys/ tpx019

Piao, S., Friedlingstein, P., Ciais, P., Viovy, N., and Demarty, J. (2007). Growing season extension and its impact on terrestrial carbon cycle in the Northern Hemisphere over the past 2 decades. Global Biogeochem. Cy. 21, GB3018. doi: 10.1029/2006GB002888

Polgar, C. A., and Primack, R. B. (2011). Leaf-out phenology of temperate woody plants: from trees to ecosystems. New Phytol. 191, 926-941. doi: 10.1111/ j.1469-8137.2011.03803.x

Polgar, C. A., Gallinat, A., and Primack, R. B. (2013). Drivers of leaf-out phenology and their implications for species invasions: insights from Thoreau's Concord. New Phytol. 202, 106-115. doi: 10.1111/nph.12647

Régnière, J., St-Amant, R., and Béchard, A. (2014). BioSIM 10 user's manual. Natural Resources Canada, Canadian Forest Service, Laurentian Forestry Centre. Inf. Rep. LAU-X-137E.

Repo, T. (1992). Seasonal changes of frost hardiness in Picea abies and Pinus sylvestris in Finland. Can. J. For. Res. 22, 1949-1957. doi: 10.1139/ x92-254

Rossi, S., and Bousquet, J. (2014). The bud break process and its variation among local populations of boreal black spruce. Front. Plant Sci. 5, 574. doi: 10.3389/ fpls.2014.00574
Rossi, S., and Isabel, N. (2016). Bud break responds more strongly to daytime than night-time temperature under asymmetric experimental warming. Glob. Change Biol. 23, 446-454. doi: 10.1111/gcb.13360

Rossi, S., and Isabel, N. (2017). The timing of bud break in warming conditions: variation among seven sympatric conifer species from Eastern Canada. Int. J. Biometeorol. 61, 1983-1991. doi: 10.1007/s00484-017-1391-4

Rossi, S. (2015). Local adaptations and climate change: converging sensitivity of bud break in black spruce provenances. Int. J. Biometeorol. 59, 827-835. doi: 10.1007/s00484-014-0900-y

Rousi, M., and Heinonen, J. (2007). Temperature sum accumulation effects on within-population variation and long-term trends in date of bud burst of European white birch (Betula pendula). TreePhysiol 27, 1019-1025. doi: 10.1093/treephys/27.7.1019

Snyder, R. L., Spano, D., Cesaraccio, C., and Duce, P. (1999). Determining degreeday thresholds from field observations. Int. J. Biometeorol. 42, 177-182. doi: $10.1007 / \mathrm{s} 004840050102$

Soolanayakanahally, R. Y., Guy, R. D., Silim, S. N., and Song, M. (2013). Timing of photoperiodic competency causes phenological mismatch in balsam poplar (Populus balsamifera L.). Plant Cell Environ. 36, 116-127. doi: 10.1111/j.13653040.2012.02560.x

Stott, P. A., Christidis, N., Otto, F. E. L., Sun, Y., Vanderlinden, J.-P., van Oldenborgh, G. J., et al. (2015). Atribution of extreme weather and climaterelated events. Wires Climate Change 7, 23-41. doi: 10.1002/wcc.380

Sutinen, S., Partanen, J., Viherä-Aarnio, A., and Häkkinen, R. (2012). Development and growth of primordial shoots in Norway spruce buds before visible bud burst in relation to time and temperature in the field. Tree Physiol. 32, 987-997. doi: 10.1093/treephys/tps063

Sylvestro, R., Rossi, S., Zhang, S., Froment, I., Huang, J. G., and Saracino, A. (2019). From phenology to forest management: ecotypes selection can avoid early or late frosts, but not both. For. Ecol. Manage. 436, 21-26. doi: 10.1016/ j.foreco.2019.01.005

Tang, J., Körner, C., Muraoka, H., Piao, S., Shen, M., Thackeray, S. J., et al. (2016). Emerging opportunities and challenges in phenology: a review. Ecosphere 7, e01436. doi: $10.1002 /$ ecs2.1436

Verkerk, P. J., Costanza, R., Hetemäki, L., Kubiszewskj, I., Leskinen, P., Nabuurs, G. J., et al. (2020). Climate-smart forestry: the missing link. For. Policy Econom. 115, 102164. doi: 10.1016/j.forpol.2020.102164

Vitasse, Y., Signarbieux, C., and Fue, Y. H. (2018). Global warming leads to more uniform spring phenology across elevations. Proc. Natl. Acad. Sci. U. S. A. 115, 1004-1008. doi: 10.1073/pnas.1717342115

Vitra, A., Lenz, A., and Vitasse, Y. (2017). Frost hardening and dehardening potential in temperate trees from winter to budburst. New Phytol. 216, 113 123. doi: $10.1111 /$ nph. 14698

Wang, Y., Case, B., Rossi, S., Zhu, L., Liang, E., and Ellison, A. (2019). Frost controls spring phenology of juvenile Smith fir along elevational gradients on the southeastern Tibetan Plateau. Int. J. Biometeorol. 63, 963-972. doi: 10.1101/158733

Worrall, J., and Mergen, F. (2006). Environmental and genetic control of dormancy in Picea abies. Physiol. Plantarum 20, 733-745. doi: 10.1111/ j.1399-3054.1967.tb07217.x

Yakovlev, I., Gunnar Fossdal, C., Johnsen, Ø., and Junttila, O. (2006). Analysis of gene expression during bud burst initiation in Norway spruce via ESTs from subtracted cDNA libraries. Tree Genet. Genomes 2, 39-52. doi: 10.1007/ s11295-005-0031-z

Conflict of Interest: The authors declare that the research was conducted in the absence of any commercial or financial relationships that could be construed as a potential conflict of interest.

Copyright (c) 2020 Marquis, Bergeron, Simard and Tremblay. This is an open-access article distributed under the terms of the Creative Commons Attribution License (CC BY). The use, distribution or reproduction in other forums is permitted, provided the original author(s) and the copyright owner(s) are credited and that the original publication in this journal is cited, in accordance with accepted academic practice. No use, distribution or reproduction is permitted which does not comply with these terms. 